\title{
Episodic Dissolution, Precipitation, and Slip along the Heart Mountain Detachment, Wyoming
}

\author{
Erika Swanson, ${ }^{1}$ Brian P. Wernicke, ${ }^{1, \star}$ and Thomas A. Hauge ${ }^{2}$ \\ 1. Division of Geological and Planetary Sciences, California Institute of Technology, Pasadena, \\ California 91125, USA; 2. 3519 South Main Street, Seattle, Washington 98144, USA
}

\begin{abstract}
A B S T R A C T
The Heart Mountain allochthon is among the largest landslide masses in the rock record. The basal fault, the Heart Mountain detachment, is an archetype for the mechanical enigma of brittle fracture and subsequent frictional slip on low-angle faults, both of which appear to occur at ratios of shear stress to normal stress far below those predicted by laboratory experiments. The location of the detachment near the base of thick cratonic carbonates, rather than within subjacent shales, is particularly enigmatic for frictional slip. A broad array of potential mechanisms for failure on this rootless fault have been proposed, the majority of which invoke single-event, catastrophic emplacement of the allochthon. Here, we present field, petrographic, and geochemical evidence for multiple slip events, including crosscutting clastic dikes and multiple brecciation and veining events. Cataclasites along the fault show abundant evidence of pressure solution creep. Banded grains, which have been cited as evidence for catastrophic emplacement, are associated with stylolitic surfaces and alteration textures that suggest formation through the relatively slow processes of dissolution and chemical alteration rather than dynamic suspension in a fluid. Temperatures of formation of faultrelated rocks, as revealed by clumped isotope thermometry, are low and incompatible with models of catastrophic emplacement. We propose that displacement along the gently dipping detachment was initiated near the base of the carbonates as localized patches of viscous yielding, engendered by pressure solution. This yielding, which occurred at very low ratios of shear stress to normal stress, induced local subhorizontal tractions along the base of the allochthon, raising shear stress levels (i.e., locally rotating the stress field) to the point where brittle failure and subsequent slip occurred along the detachment. Iteration of this process over geological time produced the observed multikilometer displacements. This concept does not require conditions and materials that are commonly invoked to resolve the stress paradox for low-angle faults, such as near-lithostatic fluid pressures or relative weakness of phyllosilicates in the brittle regime. Cyclic interaction of viscous creep (here by pressure solution) and brittle failure may occur under any fluid pressure conditions and within any rock type, and as such it may be an attractive mechanism for slip on "misoriented" fault planes in general.
\end{abstract}

Online enhancements: appendix.

\section{Introduction}

Fracture and slip on shallowly dipping detachments is one of the longest-debated puzzles in tectonics. In the case of both large-runout landslides and rooted, low-angle normal faults, it is generally agreed that one of the principal stress axes (presumably, the maximum principal stress) is subvertical, and so in both cases the central mechanical problem is how the system overcomes coulombic failure criteria. According to the classic Andersonian theory of fault mechanics, which assumes coulombic failure criteria with one

Manuscript received October 31, 2014; accepted September 9, 2015; electronically published January 8, 2016.

* Author for correspondence; e-mail: brian@gps.caltech.edu. vertical principal stress axis, the ratio of shear stress to normal stress is far too low for both initiation and continued slip on normal faults dipping $<30^{\circ}$ (e.g., Axen 2004). Even under the ambient condition of lithostatic pore fluid pressure, slip along low-angle planes is not predicted to occur before more favorably oriented slip planes are all well above their failure criteria (e.g., Collettini 2011). However, many geologists have documented that the dominant structures in the upper crust in extensional environments (including areas of landsliding and salt tectonics) are often shallowly dipping detachments (e.g., Armstrong 1972; Davis and Coney 1979; Pierce 1980; Allmendinger et al. 1983; Wernicke et al. 1985; Hauge 1985, 
1990; Lister and Davis 1989; Wernicke 1995; Morley 2014).

The Eocene Heart Mountain detachment in northwestern Wyoming is among the largest, best-studied examples of such an enigmatic feature (fig. 1). Exposures of the upper plate of the detachment, the Heart Mountain allochthon, form an elongate, internally coherent, extended mass comprising Paleozoic carbonate strata and overlying Eocene Absaroka volcanics. The allochthon is at least $70 \mathrm{~km}$ long, with apparent slip of as much as $45 \mathrm{~km}$ (e.g., Pierce 1980). At present, the base of the allochthon is subhorizontal $\left(<10^{\circ} \mathrm{dip}\right)$ and is exposed within a narrow range of elevation ( 1800-2800 m). A contour map of the fault surface defines a gently warped dome-and-basin structure, with little or no systematic slope over its area of exposure (fig. 2).

Since its discovery in the late nineteenth century, varied aspects of the origin and emplacement history of the Heart Mountain allochthon have been hotly debated. A conspicuous klippe of Paleozoic carbonates over Eocene sedimentary units in the basin at Heart Mountain (fig. 1) was first recognized by Eldridge (1894) and was described again by Fisher (1906). Further study revealed more apparent klippen to the west with similar structural characteristics, leading Dake (1918) to suggest emplacement by thrust faulting. The observation that the hanging-wall structure primarily reflects horizontal extension led Bucher (1947) to suggest that the allochthon, comprising Paleozoic blocks, was emplaced rapidly as discontinuous "individual fragments," perhaps in response to seismic activity antecedent to volcanism.

The detachment zone and environs were first systematically mapped at relatively small scale by a USGS team led by W. G. Pierce (Pierce 1965a, 1965b, 1966, 1978; Pierce and Nelson 1968, 1969, 1971; Pierce et al. 1973, 1982; Prostka et al. 1975; Nelson et al. 1980). These workers also concluded that the allochthon was emplaced just prior to most local Absaroka volcanism, leaving much of the original detachment surface subaerially exposed, effectively as a large-scale landslide scar (Pierce 1957, 1973). According to this "tectonic denudation" hypothesis (Pierce 1960, p. B237), before significant erosion had occurred the exposed surface was unconformably overlain by a thick sequence of postemplacement volcanic strata.

Kinematics: Catastrophic versus Gradual Emplacement. The denudation hypothesis raised two fundamental questions about the kinematics of displacement that must be addressed before any serious attempt can be made toward understanding the mechanics of slip along the detachment. The first is whether the allochthon was a contiguous mass during emplacement or was fragmented into isolated blocks. The second is whether emplacement was catastrophic (occurring in a few minutes or hours) or gradual, perhaps occurring on a million-year time scale.

With regard to the first question, a detailed, systematic structural analysis of the best-exposed traces of the contact between the putatively postemplacement volcanics and the footwall of the detachment suggested that volcanic rocks in contact with the footwall are generally tilted and faulted against it, not extruded onto it (Hauge 1982). These observations led to the hypothesis that the hanging wall of the detachment, on the eastern flank of the extensive Absaroka volcanic field, deformed as a continuous, extending allochthon above a detachment plane that remained in the subsurface throughout its movement history rather than being denuded and, briefly, subaerially exposed prior to magmatism (Hauge 1985).

With regard to the second question, Hauge (1985, 1990) and Beutner and Hauge (2009) proposed that the allochthon was emplaced, at least in part, gradually rather than catastrophically. They cited structural features in the allochthon-such as calcite growth fibers along faults, mesoscale superposition relations among diking and faulting that require more than one event, and multiple brecciation events - that indicate at least some progressive deformation rather than a single catastrophic event. Furthermore, biotite Ar-Ar plateau ages determined on a trachytic ashflow tuff (50.01 $\pm 0.14 \mathrm{Ma}$ ) that overlaps the "breakaway" fault in its northeasternmost area of exposure (fig. 1) are significantly older than the age of a monzogabbro intrusion (48.21 $\pm 0.08 \mathrm{Ma}$; Hiza 2000) that is cut by the fault in its central area of exposure at White Mountain (fig. 1), suggesting that the allochthon was active over a period of nearly $2 \mathrm{~m}$.yr.

At present, there is thus apparent consensus that the allochthon is a continuous, extended mass in which large volumes of volcanics are involved in faulting and that, given its extant area of exposure of $>2100 \mathrm{~km}^{2}$, it constitutes perhaps the largest known subaerial landslide in the geological record (Beutner and Gerbi 2005; Beutner and Hauge 2009; Goren et al. 2010; Craddock et al. 2012; Anders et al. 2013). However, opinion remains sharply divided on the kinematic question of the whether emplacement was catastrophic (Anders et al. 2010; Goren et al. 2010; Craddock et al. 2012) or, at least in part, gradual (Hauge 1985, 1990; Beutner and Hauge 2009|, limiting progress toward understanding the dynamics of slip.

Dynamics: The Stress Paradox. The debate about the mechanics of slip has traditionally been influenced by two long-standing issues related to stresses that drive low-angle faulting - (1) their unfavorable 


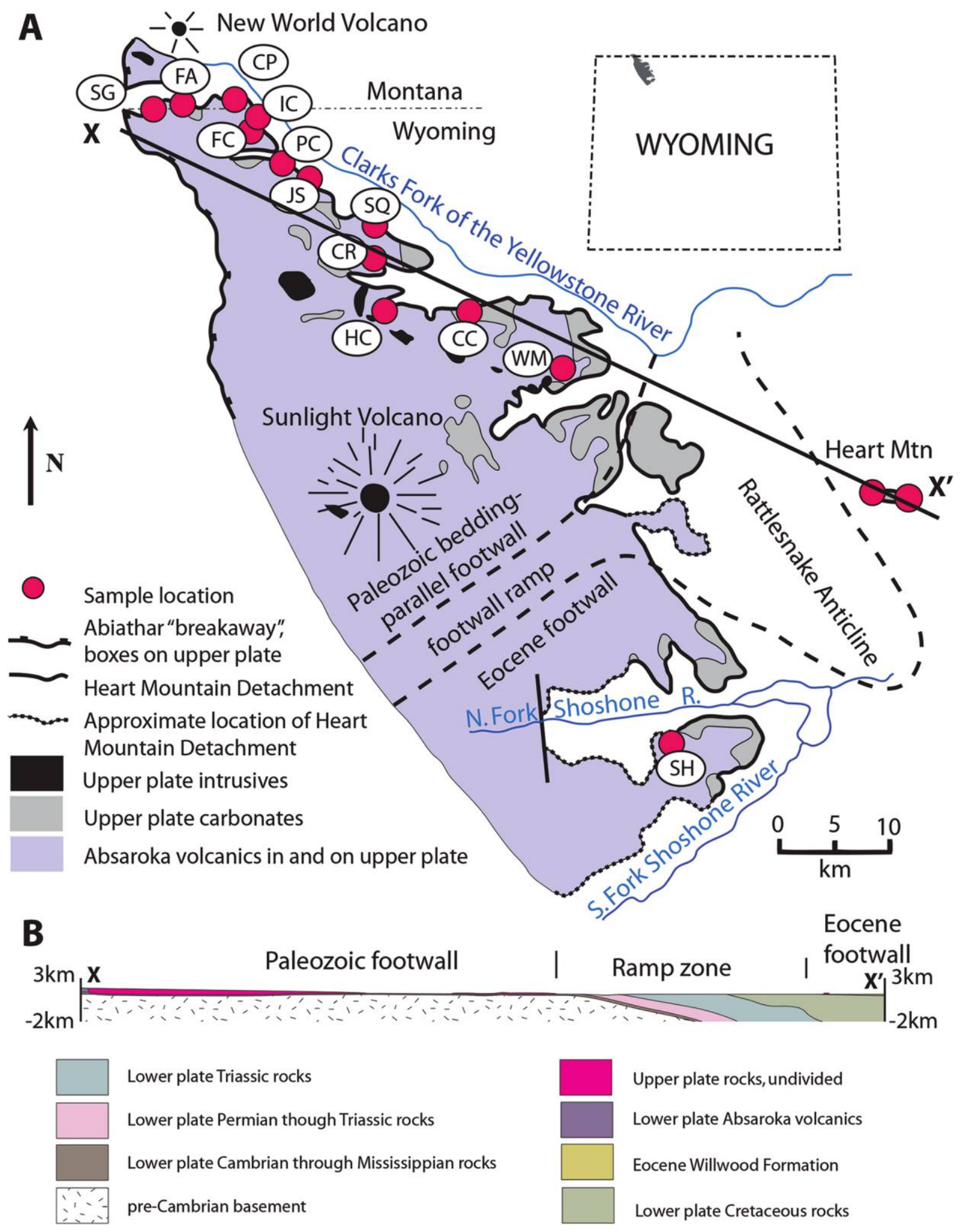

Figure 1. A, Simplified geologic map of the Heart Mountain allochthon showing trace of the basal detachment, distribution of carbonate and volcanic components, footwall sections, location of cross section in $B$, and localities discussed in the text, from north to south: SG = Silver Gate; FA = Falls Creek; $\mathrm{CP}=$ Colter Pass; IC = Index Creek; FC = Fox Creek; PC = Pilot Creek; JS = Jim Smith Creek; SQ = Squaw Creek; CR = Crandall Creek; HC = Hoodoo Creek; $\mathrm{CC}=$ Cathedral Cliffs; WM = White Mountain; SH = Sheep Mountain. B, Cross section X-X' $(1: 1)$ through Heart Mountain allochthon and substrate. 


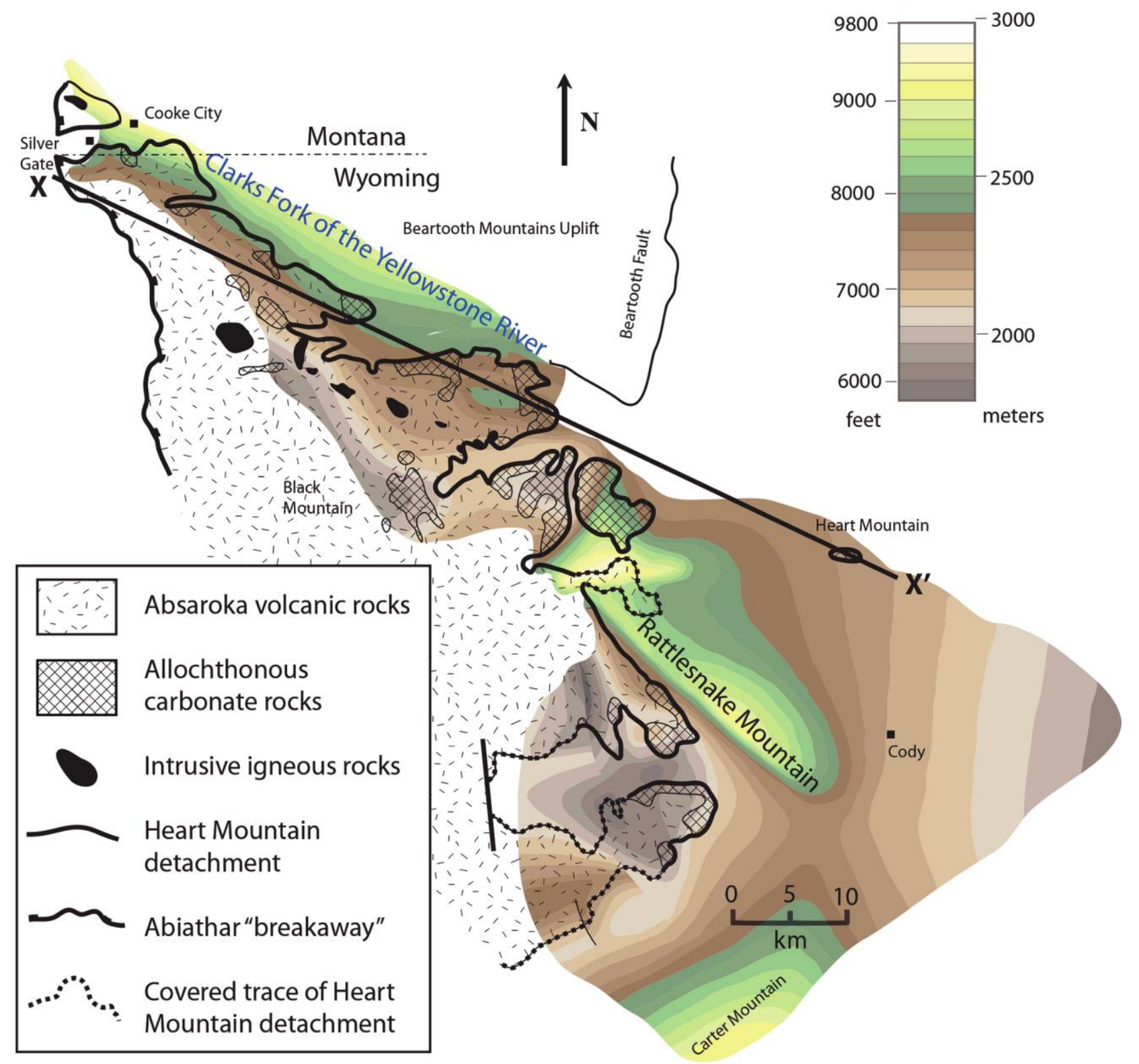

Figure 2. Contour map of the Heart Mountain detachment surface. Line $\mathrm{X}-\mathrm{X}^{\prime}$ is the same as that shown in figure 1 . Modified from Pierce (1980).

orientation in the context of Andersonian mechanics (e.g., Collettini and Sibson 2001) and (2) the potential role played by pore fluid pressure acting on an impermeable allochthon-in resolving the paradox (Hubbert and Rubey 1959; Rubey and Hubbert 1959|. In the case of Heart Mountain, the dip during initiation and slip is very low (fig. 2), making the stress ratio problem particularly acute. In addition, the allochthon is thin $(\sim 1-2 \mathrm{~km}$; aspect ratio, $\sim 50: 1$; fig. $1 B$ ) and its base includes highly fractured, presumably highly permeable carbonates, making both the development and the maintenance of elevated fluid pressure problematic (Davis 1965).
Given these facts, any mechanical conception of the Heart Mountain detachment as forming catastrophically has at its disposal a broad palette of extraordinary circumstances affecting an area of thousands of square kilometers (e.g., fluid overpressure, magmatic devolatilization, seismic accelerations, bolide impact) that need to operate only for as little as a few seconds prior to emplacement rather than a million years or more (e.g., Hughes 1970; Pierce 1973, 1980; Voight 1973; Melosh 1983; Sales 1983; Beutner and Gerbi 2005; Aharonov and Anders 2006; Craddock et al. 2009, 2012; Anders et al. 2010, 2013). The gradual emplacement hypothesis, on the other hand, 
restricts the system to processes that either function continuously or are at least repeatable thousands of times on a million-year time scale (e.g., Hauge 1982, 1985, 1990, 1993a; Templeton et al. 1995; Hiza 2000; Douglas et al. 2003; Beutner and Hauge 2009). As such, the gradual emplacement model, if correct, starkly exposes traditional conceptions of brittle fault mechanics as having little explanatory power.

The implicit assumption that fault displacement in the upper crust is controlled entirely by brittle fracture and frictional sliding criteria has come under question. It is clear from the rock record that significant strains in the brittle regime are accommodated by pressure solution (e.g., Engelder 1979; Wright and Platt 1982), which is likely an important factor along brittle faults (e.g., Collettini and Holdsworth 2004; Anderson et al. 2010). In contrast to other known low- to moderate-temperature deformation processes, both theoretical arguments and experimental data suggest that pressure solution in rocks and minerals has a viscous rheology (e.g., Rutter 1983; Bos and Spiers 2001). Gratier et al. (2002, 2013) have described how pressure solution creep and crack sealing may exert significant control over the seismic cycle and mechanics of strike-slip faults. If pressure solution creep played a significant role in Heart Mountain faulting, the mechanics of low-angle faulting in general may benefit from reevaluation.

With the issues of catastrophic versus gradual emplacement and the potential role of fluid-assisted deformation in mind, we conducted a detailed mesoscopic and microscopic analysis of structural features on and near the Heart Mountain detachment in key localities, in coordination with a sampling program to study the temperature and isotopic composition of fluids associated with faulting using carbonate clumped-isotope thermometry. Here we report the results of our analysis of mesoscopic and microscopic structural features as well as clumped-isotope data pertinent to their interpretation. Elsewhere, we present the bulk of our isotopic results that bear on the origin and evolution of fluids along the fault (Swanson 2015).

\section{Heart Mountain Detachment and Extensional Allochthon}

At large scale, the Heart Mountain detachment is divisible into three main areas on the basis of the footwall detachment level, which from northwest to southeast includes the Paleozoic, ramp, and Eocene footwall sections (Pierce 1980; fig. 1). The detachment initiated predominantly as a decollement within the Paleozoic section, ramping steeply upward across Paleozoic and Mesozoic strata, and then cutting gently upsection to the southeast within Eocene strata. The hanging wall, or "extensional allochthon," more than doubled in areal extent as a result of internal extension, bringing Eocene volcanic rocks down into direct contact with the Paleozoic footwall and translating Paleozoic strata in the hanging wall over Eocene sediments of the Bighorn basin.

The carbonate component of the allochthon is a cratonic Paleozoic section $\sim 500 \mathrm{~m}$ thick, ranging in age from Ordovician to Mississippian. The overlying volcanic component includes Eocene volcanic strata of the Absaroka Volcanic Supergroup (ca. 52$48 \mathrm{Ma}$ ) and related dikes and small intrusive bodies. The basal decollement formed within a remarkably narrow stratigraphic interval $(<5 \mathrm{~m})$ near the base of the Ordovician Bighorn Dolostone (e.g., Pierce 1973). Because of internal distension of the allochthon, both Paleozoic and overlying Tertiary components of the allochthon are juxtaposed with the footwall (e.g. Hauge 1985, 1990).

The fault lies along the eastern margin of the extensive Absaroka volcanic field and was active during Absaroka magmatism (e.g., Hiza 2000; Douglas et al. 2003; Feeley and Cosca 2003). Above the Paleozoic footwall section of the detachment, the allochthon is largely cospatial with the Sunlight volcano and is bounded to the northwest by the New World volcano (fig. 1). The principal components of the Sunlight volcano include $\sim 1500 \mathrm{~m}$ of intermediate to mafic flows of the Wapiti Formation (ca. 50-49 Ma) and overlying Trout Peak Trachyandesite (ca. 48.548.1 Ma; Feeley and Cosca 2003), along with a welldeveloped radial dike swarm and scattered small plutons. Because of these temporal and spatial relations, the elongate allochthon is generally regarded as a sector collapse, generally southeastward toward the Laramide Bighorn basin (e.g., Beutner and Hauge 2009; Anders et al. 2010).

The detachment forms a remarkably flat, planar structure that is readily identifiable in the field, even from distances of a kilometer or more (fig. $3 A, 3 B$ ). Below the detachment in the Paleozoic footwall, bedding within the Ordovician Bighorn Dolostone and Cambrian Snowy Range Formation is usually subhorizontal (dips $<10^{\circ}$ ), structurally intact, and parallel to the detachment. In some places, the footwall is virtually undeformed below the detachment, maintaining its original form to within a millimeter or less of the fault (e.g., Anders et al. 2010). In others, significant deformation has affected the footwall below the fault (see the discussion below).

In contrast to the footwall, the allochthon is pervasively faulted at kilometer scale, with hanging-wall strata of both Paleozoic and Tertiary age commonly tilted to moderate dips of $20^{\circ}-50^{\circ}$ (fig. 2 in Hauge 

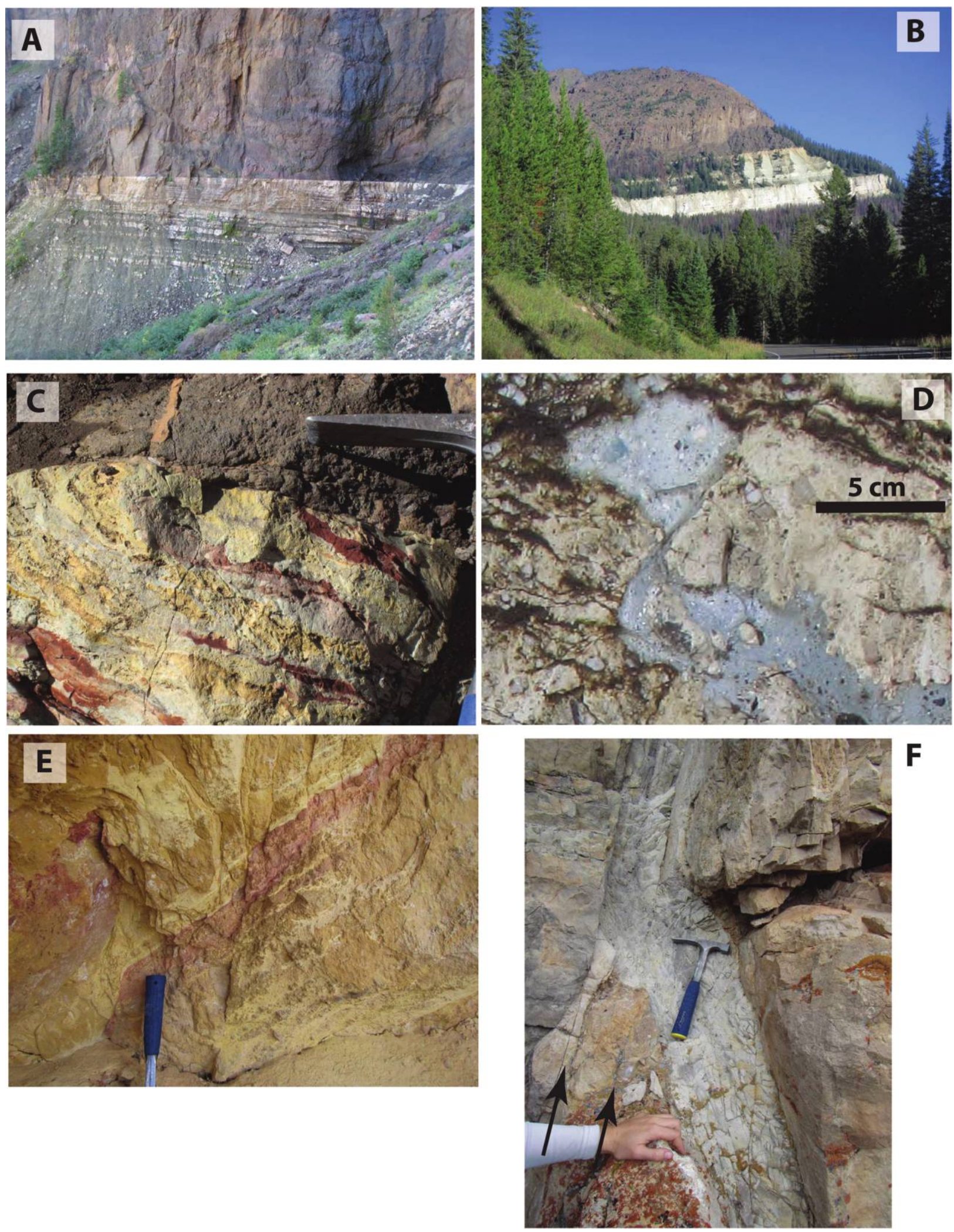

Figure 3. Photographs of megascopic to mesoscopic structural features associated with the Heart Mountain allochthon. A, Heart Mountain detachment (sharp horizon between dark and light rocks) at Jim Smith Creek (fig. 1), looking south. The dark-brown rocks above the fault are Absaroka volcanics; the massive light-brown cliff below the fault is the lower $5 \mathrm{~m}$ of the Bighorn Formation. The light- and dark-banded unit below the Bighorn Formation is the Cambrian Snowy Range Formation. B, Heart Mountain detachment (sharp contact between dark and light rocks) above Index Creek. The 
1985). Hanging-wall faults are often associated with veins filled with sparry calcite, ranging from millimeter to centimeter scale in width. These veins in places exhibit calcite growth fibers, inferred to represent evidence for gradual displacement (e.g., Hauge $1993 b$ ). Adjacent to the detachment, the allochthon is typically cut by numerous mesoscale, slickensided faults and shattered into jigsaw breccia, autobreccia, and fault gouge (Hauge 1985). Brecciation occurs at a distance of up to tens of meters above the fault plane. In some places, a tabular, texturally distinct layer ("basal layer" of Anders et al. 2010) occurs directly on the fault plane, usually $\sim 1 \mathrm{~mm}$ thick but in one notable locality (White Mountain; fig. 1) 3 m thick. In most places along the fault, clastic dikes filled with fine-grained breccia and gouge are injected into the hanging wall. They occur most commonly within $\sim 100 \mathrm{~m}$ vertically above the detachment plane (Pierce 1979; Hauge 1985). They range from $\sim 1 \mathrm{~cm}$ up to $1 \mathrm{~m}$ in width and exhibit diverse orientations relative to the detachment. Boundaries of the dikes may be either planar and parallel to one another or highly irregular.

\section{Observations}

We visited 11 sites along the exposed trace of the Heart Mountain detachment, making mesoscopic observations of field relations and collecting 80 carbonate samples for petrographic and geochemical analysis, including fault rocks, clastic dikes, veins, and Paleozoic host rocks, spanning a northwest-southeast distance of $70 \mathrm{~km}$, from near the "breakaway" in the northern part of the allochthon to its "toe" in the Bighorn basin at Heart Mountain (fig. 1). Including some 80 thin sections archived from an earlier study (Hauge 1983), we analyzed a total of 117 thin sections using a petrographic microscope. To verify petrographically based mineral identifications, a subset of eight samples was analyzed, using scanning electron microscope imaging and energy dispersive X-ray spectroscopy. We performed a total of 83 carbonate clumped-isotope analyses from our sample suite, six of which are presented here because of their relevance to superposition relationships along the detachment zone, with the re- mainder presented in Swanson (2015). A brief description of analytical methods for clumped-isotope thermometry is presented in the appendix (available online).

Mesostructural Observations. We observed cataclasis in the footwall, from thin-section scale up to several meters below the detachment. Localities where we observed footwall cataclasis include, from north to south, Silver Gate, Colter Pass, Jim Smith Creek, Pilot Creek, Cathedral Cliffs, and Hoodoo Creek. Among the best developed of these zones is at Jim Smith Creek. There, the upper 2-3 m of Bighorn Formation below the detachment developed a structural fabric (primarily foliation) through intense brecciation and fluid alteration. This fabric is truncated by the detachment (fig. 3A, 3C).

There is also macroscopic evidence of polyphase brittle deformation, where older fault-related features are offset or folded by younger ones. These features are geometrically complex and not ubiquitous enough to draw conclusions about their structural fabric but nonetheless are readily observed at several localities. For example, at Fox Creek, Heart Mountain, and Crandall Creek (fig. $3 D, 3 E$, and $3 F$, respectively), earlier gouge zones or clastic dikes are overprinted by faulting, flexure, and brecciation in association with mesoscale faults.

At Fox Creek, 5-10 $\mathrm{m}$ above the detachment, evidence for multiple episodes of injection of clastic dikes is observed, with both cross-cutting dikes and "sheeting" or multiphase injection apparent within the same dike (fig. 4). There, the widest dike is $\sim 10 \mathrm{~cm}$ thick, with a darker, older injection phase preserved along the margins overprinted by a lighter, younger phase (fig. $4 A, 4 B$ ). The lighter core phase has a lower percentage of coarse clasts than the darker phase on the margin. The lighter core phase of the main dike is physically contiguous with a thinner dike that projects into the country rock, where it sharply truncates two older dikes at right angle, one of which is a darker, fine-grained phase and the other a lighter, coarse-grained phase (fig. 4C). Both relationships suggest at least two episodes of injection. In addition, the host rock itself is strongly brecciated Bighorn Formation, requiring a third, older event to cause the

light-colored cliffs are $200 \mathrm{~m}$ high. C, Heart Mountain detachment (base of dark-brown unit) showing brecciated and mineralized layering in the Bighorn Formation in footwall truncated by fault. A light-brown, centimeter-scale clastic dike is visible at upper left. Jim Smith Creek, looking southwest, hanging-wall transport direction top left. A hammer is shown for scale. $D$, Clastic dike intruding lineated cataclasite, subsequently drag-folded and offset by mesoscale fault, Fox Creek. $E$, Offsets of hematitic foliated gouge within hanging-wall fault zone, Heart Mountain. A hammer is shown for scale. $F$, Clastic dike (beneath hammer) deformed by flexure and jigsaw brecciation in association with small hanging-wall faults (black arrows), Crandall Creek. 


\section{A}
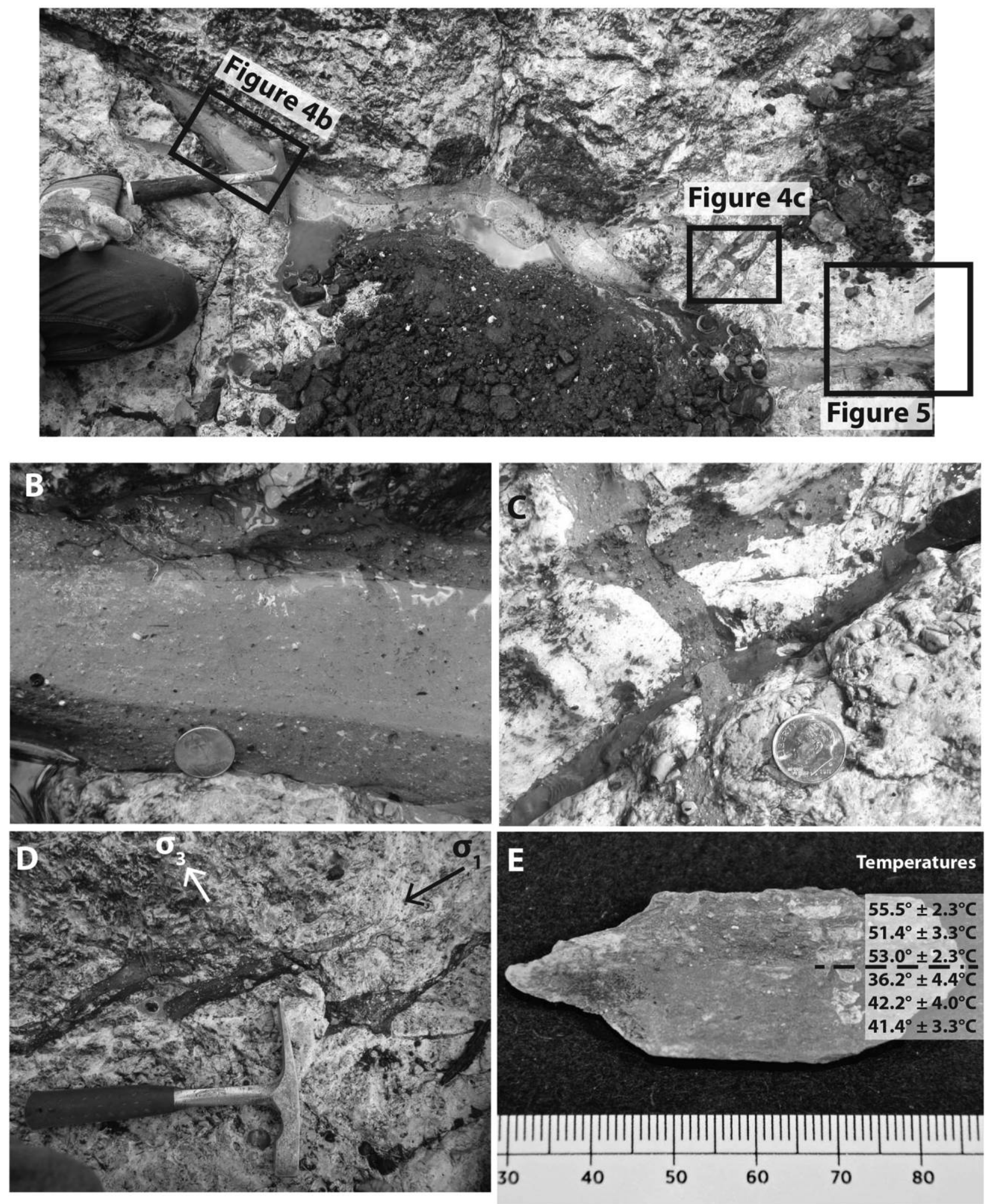

Figure 4. Photographs of clastic dikes at Fox Creek $\sim 5-10 \mathrm{~m}$ above the Heart Mountain detachment. $A$, Overview looking southwest and downward at $45^{\circ}$ angle. Black outlines show locations of $B, C$, and figure 5 . The hammer is $28 \mathrm{~cm}$ long. $B$, Close-up of two-toned clastic dike. The coin is $21 \mathrm{~mm}$ in diameter. $C$, Cross-cutting clastic dikes, with older light- and younger dark-gray phases, inclined to the left, truncated at high angle by a younger light-gray clastic dike. The coin is $18 \mathrm{~mm}$ in diameter. $D$, View west of en echelon clastic dikes, with hammer handle oriented parallel to detachment. Arrows indicate implied maximum $\left(\sigma_{1}\right.$, black $)$ and minimum $\left(\sigma_{3}\right.$, white) principal stress orientations. $E$, Hand sample of main two-toned clastic dike shown in $B$, showing microdrill pits and corresponding carbonate clumped-isotope temperatures. The black dashed line marks the boundary between the darker phase (upper) and lighter phase (lower) of the dike. Scale is in millimeters. A color version of this figure is available online. 
brecciation. Within a few meters of the two-toned clastic dike, there are three smaller dikes that form an en echelon pattern, each $\sim 20 \mathrm{~cm}$ long and with an apparent dip of $\sim 30^{\circ}$ toward the south (fig. $4 D$ ). Assuming the clastic dikes are tensile features and have not been tilted, they imply that the principal stress orientations at the time of injection were not vertical but rather favorable for top-south shear (fig. 4D). Additional deformation events are recorded by mesoscale fault offsets of the main clastic dike. The margin and darker, exterior phase are offset by two different faults, but the lighter, interior light-colored phase is offset by only one of the faults (fig. 5), suggesting that mesoscale faulting was active during dike injection.

In sum, given that both diking and faulting overprint brecciated country rock, we interpret there to have been at least five discrete deformational events at Fox Creek, including (1) brecciation of host Bighorn Formation, (2) injection of dark-colored phase of main clastic dike, (3) offset of the dike by $\sim 4 \mathrm{~cm}$ (left-hand fault of fig. 5), (4) injection of the light-colored phase of the clastic dike, and (5) offset of the dike by $\sim 4 \mathrm{~cm}$ (right-hand fracture in fig. 5). The brecciation and diking events must have been separated by sufficient time to lithify the material, which we presume was cohesionless at the time of formation.

Microstructural Observations. Our microstructural studies included observations of breccia clasts, banded grains, pressure-solution fabrics, and thermometric measurements, all of which bear on the kinematics (catastrophic vs. gradual emplacement) of the allochthon.

Breccia Clasts within Breccias. Evidence for breccia clasts that are themselves breccias is ubiquitous and occurs in both the hanging wall and the footwall of the detachment (fig. 6). In some cases, breccia clasts contain boundaries between clasts of volcanic fragments in a matrix of carbonate breccia (fig. 6A). In others, we observe vein systems that, although they may mainly postdate brecciation, exhibit textures suggestive of progressive deformation after brecciation had ceased (fig. 6B). In the footwall of the detachment at Jim Smith Creek, rebrecciation (fig. 6C) included examples that record the generation of three different textures of breccia (fig. 6D). Veining at this locality appears to be syntectonic with brecciation. In addition to White Mountain, Squaw Creek, and Jim Smith Creek, multiple episodes of brecciation are recorded in samples from Silver Gate, Falls Creek, Colter Pass, Fox Creek, Cathedral Cliffs, Crandall Creek, and Heart Mountain.

Some clasts contain veins that cross-cut an older brecciation event and are in turn truncated at the clast margins (fig. $6 E, 6 F$ ). The formation of tex- tures such as these record, at a minimum, the following sequence of events: (1) brecciation of host rock, (2) lithification of the resulting granular material, (3) fracture and progressive precipitation of vein fill, (4) a second brecciation event, and (5) final lithification. Further repetitions of steps 1 and 2 are indicated for clasts with more than two brecciation events, as in figure $6 D$. Because each brecciation event reduces the average grain size of previous events, it would seem unlikely that any given sample would have the capacity to record more than a few events, regardless of the total number of events accommodated by the fault. The observed textures, in other words, may well be saturated in terms of their ability to record a much larger number of events than those observed.

Banded Grains. Heart Mountain detachment breccias, particularly at White Mountain, contain rounded grains with concentric color banding (fig. 7). Except at White Mountain, these grains tend to be scarce. First noted by Hughes (1970), they have variously been referred to as "accreted grains," "armored grains," or "mantled grains" by Beutner and Craven (1996, their fig. 4), Beutner and Gerbi (2005, their figs. 6 and 7), Craddock et al. (2012, their fig. 3), Anders et al. (2010, their figs. $3 d$ and 4), and Craddock et al. (2009, their fig. 3e). We prefer instead the nomenclature "banded grain" as a nongenetic, wholly descriptive term because it does not presuppose that the banding represents augmentation of a preexisting grain, as implied by the genetic terms "mantled," "armored," and "accreted."

These grains show considerable diversity in their appearance, but all consist of a core grain surrounded by a dark band. There is no apparent pattern with regard to the size or composition of the banded grains versus normal grains. Electron probe microanalysis of a number of grains shows that the spectacular banding apparent petrographically at millimeter scale is not apparent in electron backscatter images or compositional maps. Major cation ratios are not significantly affected by the color banding, indicating that it originates from micron-scale or smaller trace mineralization. In some instances, both inside and outside the exterior dark band, the matrix exhibits concentric flattening, with long axes oriented tangentially to the core. Beyond these similarities, the grains may be subdivided into two main types, which we will refer to informally here as type 1 and type 2 .

In type 1 grains, a rigid core differs little from the matrix, and there is a single band of dark material that surrounds it. Outside the dark band, the matrix sometimes exhibits inhomogeneous, concentric flattening, forming a diffuse, exterior "halo" up to several grain radii outward from the dark band 

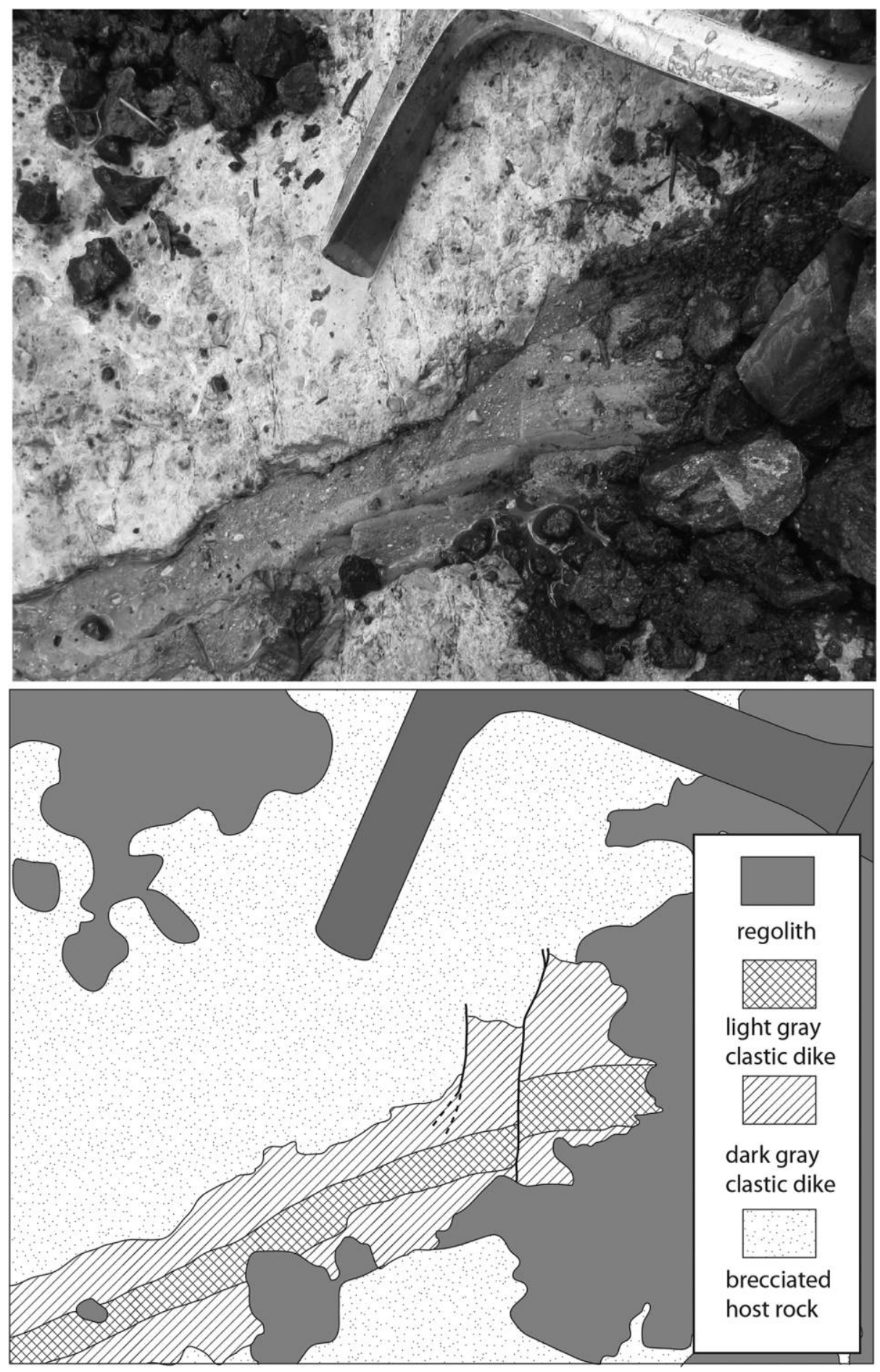

Figure 5. Photograph and interpretive line drawing of a clastic dike, suggesting five discrete episodes of injection and deformation: (1) brecciation of the host rock, (2) injection of the dark-gray (diagonal ruled) clastic dike, (3) offset along the left fault, (4) injection of the light-gray (cross-hatched) clastic dike, and (5) offset of both clastic dikes along the right fault. A color version of this figure is available online.

(figs. $7 A-7 D, 8 B$ ). In one instance, we observed a strongly flattened type 1 banded grain within the halo, implying that the formation of these grains is a protracted process (fig. $7 B$ ).
In type 2 grains (fig. $7 E-7 H$ ), the core is smaller than the outer dark band, and the intervening part of the grain forms a light-colored ring, or "bleached halo," inside the grain, usually with diffuse inner and 

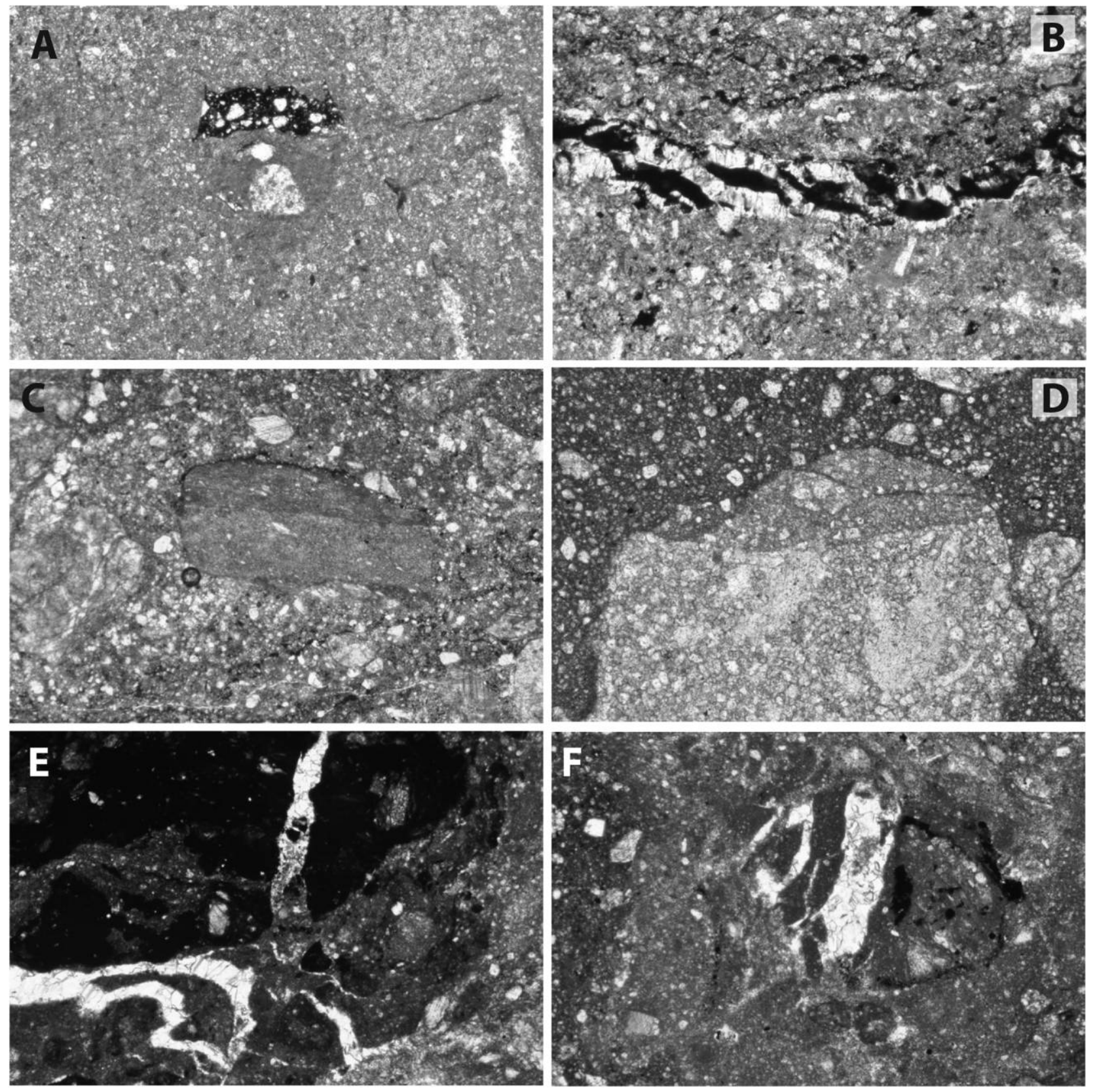

Figure 6. Photomicrographs showing multiple episodes of brecciation. All images have a 2.2-mm-wide field of view. $A$, Rounded clast (center) containing volcanic breccia (dark material at top) adjacent to carbonate breccia; hanging wall, White Mountain. $B$, Vein showing sheeted texture suggestive of progressive in-filling with calcite and Fe oxides during deformation; hanging wall, Squaw Creek. $C$, Clast of older fine-grained breccia with a rim of insoluble residues surrounded by coarser-grained, younger breccia; footwall at Jim Smith Creek. $D$, Clast with three discrete brecciation events, each with different proportion of clasts; footwall at Jim Smith Creek. E, Clast showing progressive brecciation and calcite veining; footwall at Jim Smith Creek. F, Clast preserving veining event between two episodes of brecciation. A color version of this figure is available online.

outer margins. In some examples, multiple fine-scale banding is observed within or around the margins of the grains (fig. $7 F$ ). In one example, the color pattern is reversed, with the interior halo forming a darker band than the core and outer ring. However, in gen- eral the darkest layer in the banding is at the outer edge of the grain.

The cores are diverse in composition for both grain types and include (1) volcanic phenocrysts, (2) authigenic minerals, (3) volcanic rocks and their 

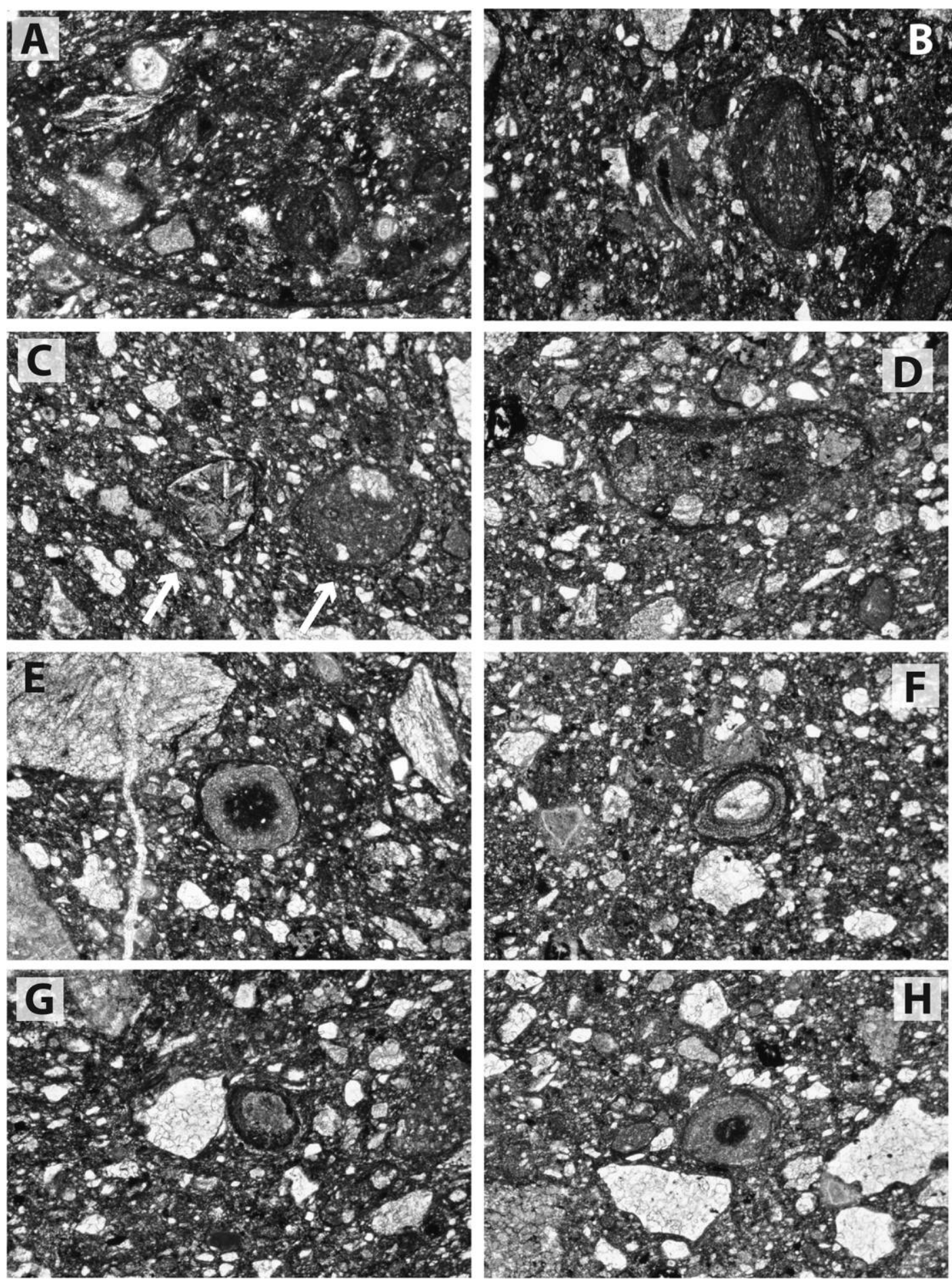

Figure 7. Photomicrographs of 12-banded grains from a single thin section from White Mountain (sample ES-HM1206). All photos have a field of view of $1.5 \times 2.2 \mathrm{~mm}$. Banded grains vary in form as well as the degree to which they visibly contrast with the host breccia. Some are defined by reaction rims; some are bounded by dark seams, not all of which are spherical; and many have dissolution seams in the matrix outside the grains, parallel to the grain boundary. A color version of this figure is available online. 


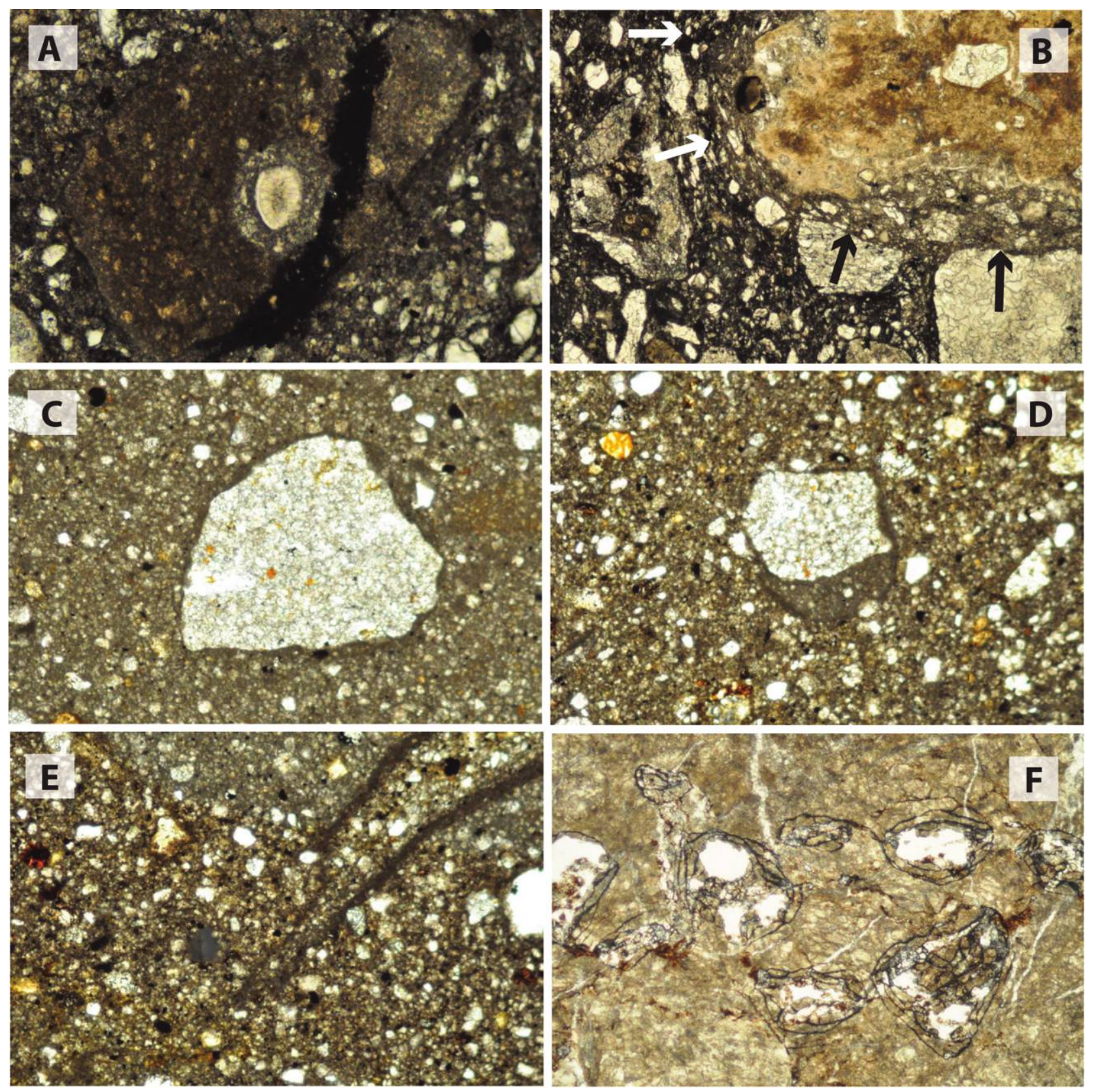

Figure 8. Photomicrographs showing textures similar to those found in banded grains. $A, B$, Detachment plane breccia, White Mountain. C-E, Clastic dike near Crandall Creek. F, Detachment plane breccia, Mormon Peak detachment, southern Nevada. Field of view is $2.2 \mathrm{~mm}$ wide except in $A$, where it is $0.9 \mathrm{~mm}$ wide. $A$, Light-colored zone of alteration overprinting older dark layer, which truncates breccia texture from an earlier event. $B$, A "brown clast" (upper right) with concentric bands of dissolution seams. Arrows show a trace of dissolution seam that truncates a rounded carbonate grain in exterior breccia; smaller grains $(\sim 100 \mu)$ have preferred orientation tangential to core grain. $C$, Rounded carbonate clast with an alteration (?) rim filling in concavities at edge. $D$, Rounded carbonate clast with an alteration rim similar to but larger than that found in C. E, Quasi-planar dissolution seams like those found in banded grains. F, Sample exhibiting round pressure solution seams associated with stylolitization, a potential precursor to banded grains at Heart Mountain. 
alteration products (clays, yellow-hued [zeolite?] grains), (4) carbonate rock, and (5) breccia, which may include both carbonate and volcanic grains. The alteration bands of both the outer dark rings and the interior bleached halos cut across older textures (fig. $7 E, 7 F$ ). In figure $8 A$, the light-brown zone of alteration surrounding a core grain overprints an older dark brown layer, which in turn truncates breccia from an earlier event.

Further observations pertinent to progressive development include evidence that pressure solution may be associated with the formation of banded grains, as shown in figure $8 B$. In this sample, a (previously) rounded carbonate grain is truncated by the dissolution seam around the edge of the banded grain. Surrounding grains in the $\sim 100-\mu$ range exhibit tangential flattening parallel to the edge of the core grain. The flattening may also reflect increased pressure solution tangential to the grain.

A few grains show rims similar to those in banded grains but with a greater variation in rim thickness (fig. 8C, 8D). The contact between the dark brown rim material and the host grain is often irregular, with concavities that we interpret to reflect alteration of the host into the rim material. A similar dark band surrounds nonspherical grains, including ones with a high aspect ratio (e.g., fig. 8E). These dark seams have a similar color and texture to stylolites but are round.

The frequency of occurrence of banded grains varies but never surpasses $10 \%$ of the area of any given thin section, with the remainder of the rock having a normal cataclastic texture. The highest percentage of banded grains (up to $10 \%$ ) is observed at White Mountain. Banded grains were common but weakly developed within a hanging-wall fault at Heart Mountain, where they comprised up to $5 \%$ of the rock. A few other localities showed banded grains, but not commonly and with poorly defined banding. These localities include clastic dikes with a large fraction of volcanics, such as those found at Crandall Creek and Jim Smith Creek. The majority of samples we collected did not show any evidence of concentrically banded grains.

Pressure Solution Creep. In the majority of samples collected, there is abundant evidence for pressure solution. Evidence includes truncation and interpenetration of contrasting textural phases (fig. 9), accumulation of iron oxide and insoluble residues (fig. $9 A, 9 B, 9 D$ ), the lack of throughgoing localized slip surfaces (fig. 9C, 9E, 9F), and ductile deformation fabrics despite shallow crustal depths $(<2000 \mathrm{~m})$ of deformation (figs. 10, 11B, 11C). With regard to the ductile deformation fabrics, asymmetric, sigmoidal banding of fault gouge is common along the Heart Mountain fault and is described in many other fault gouges. Sigmoidal geometries in layered gouges and breccias may be produced by offsets of cataclastic layering by discrete faults within the gouge layer (e.g., Cowan et al. 2003). However, they also appear to be a characteristic feature of shear via solution creep in experimental studies (fig. 11A).

A sample from Pilot Creek shows a number of pressure solution seams cross-cutting an older breccia, which are reworked into younger breccia (fig. 9D). The cross-cutting relationships require that the pressure solution features were created after the first brecciation but before the second brecciation, with enough time in between to dissolve the carbonate along the seams.

A sample from Jim Smith Creek shows a hanging wall composed of volcanic breccia overlying a footwall of carbonate breccia, separated by a 2-mm gouge zone along the detachment surface (fig. 10). A clastic dike within the hanging wall is visibly connected to and texturally identical to the gouge. The volcanic hanging wall includes both carbonate xenoliths and hornblende phenocrysts deformed into sigmoidal shapes in a shear zone within a few centimeters of the detachment plane (fig. 10). This fabric is similar to those commonly observed in midcrustal tectonites dominated by dislocation creep, but its structural position within Absaroka volcanic units precludes a depth of $>1.5 \mathrm{~km}$. Furthermore, the shear zone was syntectonic with injection of clastic dikes originating in a thin basal layer of breccia. The shear zone truncates the clastic dike and is in turn truncated by the detachment. As described below, the sigmoidal shapes of the grains within the shear zone are likely to be a textural manifestation of pressure solution along the shear zone rather than dislocation creep, which in any event is unlikely. These cross-cutting relationships indicate that pressure solution creep occurred at the same time as slip on the detachment.

Clumped-Isotope Thermometry. We measured the carbon, oxygen, and clumped-isotope compositions of a six-sample transect of samples across the color boundary of the two-toned clastic dike exposed at Fox Creek (fig. $4 E$; table 1). These results indicate that the outer, dark material (samples A, B, and C) is $13^{\circ} \mathrm{C}$ warmer than inner, light material (samples $\mathrm{D}$, $\mathrm{E}$, and $\mathrm{F}$ ), with a discrete, nongradational boundary between the two materials. Despite the temperature difference, the samples have indistinguishable bulk carbon and oxygen isotope composition. Texturally, these samples are mixtures of material, and the difference in observed temperatures can result either from different ratios of the same cold and warm material formed prior to diking or from different crystallization temperatures of material during injection. Either way, the injections of cataclasite re- 

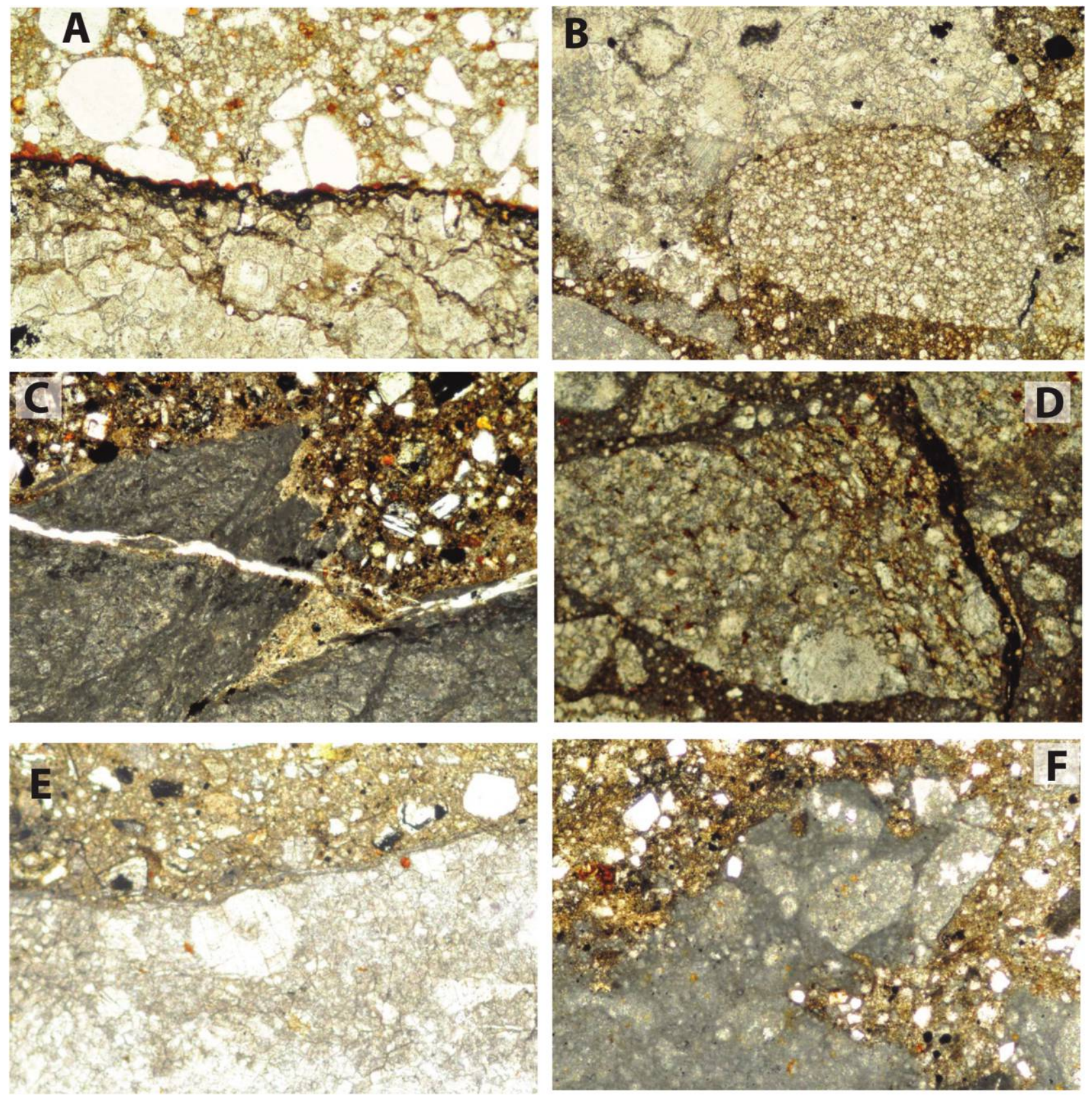

Figure 9. Photomicrographs showing different styles of pressure solution. All images are $2.2 \mathrm{~mm}$ across. $A$, Stylolite from near Index Peak, with a thick seam of iron oxide and insoluble residues. $B$, Pressure solution, with smaller, rounded grain with fine-grained texture penetrating larger, more angular grain with coarser texture; from footwall at Jim Smith Creek. C, Pressure solution and veining along highly irregular contact between carbonate (dark gray) and volcanic (brown) phases of breccia; from northwest side of Sheep Mountain. $D$, Breccia clast within breccia containing stylolites, indicating dissolution between two fragmentation-cementation events; from north of Pilot Creek. E, Irregular, stylolitic contact along Heart Mountain detachment surface at Hoodoo Creek. F, Highly irregular stylolitic contact between volcanic breccia and carbonate breccia at the detachment, south of Pilot Creek.

sponsible for the two-toned pattern were two discrete events.

The recorded temperatures $\left(36^{\circ}-56^{\circ} \mathrm{C}\right)$ are relatively cold for fault-related samples (see Swanson et al. 2012; Swanson 2015) and are much colder than might be expected for a rapidly slipping fault zone at the base of a collapsing, active volcano. The temperatures of the samples from the inner clastic dike are colder than those of the host Bighorn Formation, while the bulk carbon and oxygen iso- 

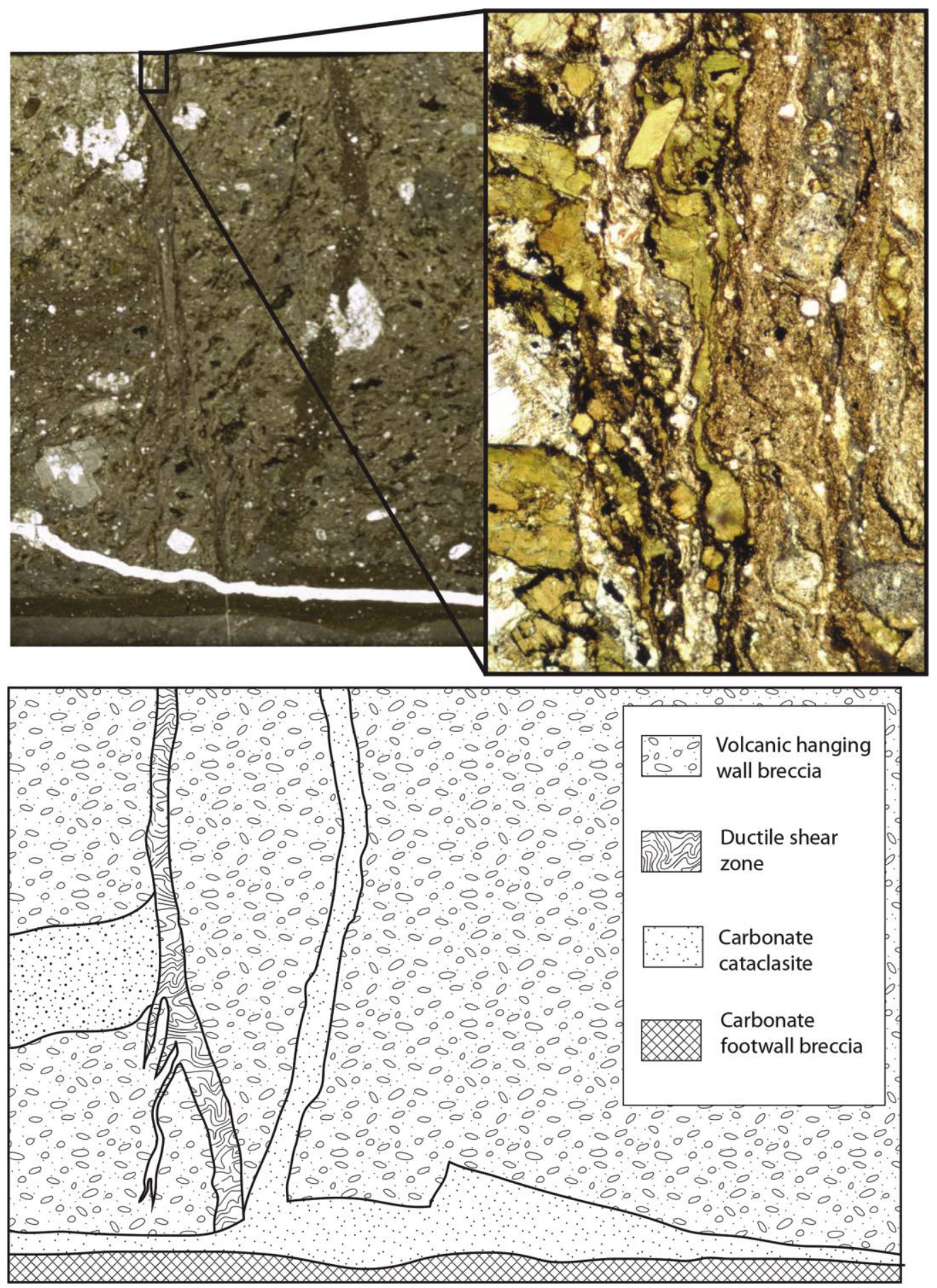

Figure 10. Photomicrograph of the Heart Mountain detachment at Jim Smith Creek and interpretive sketch of textures. Inset photo has a height of $2.2 \mathrm{~mm}$. A zone of ductile deformation offsets a clastic dike filled with carbonate breccia but is offset by the carbonate cataclasite layer on the detachment surface. Inset photo shows detail of shear zone, including sigmoidal clasts of hornblende and carbonate grains.

topes of the mineral are consistent with the host rock. The $\delta^{18} \mathrm{O}$ values of the waters in equilibrium with the samples are near the lower limit of the host rock range for the light-colored, inner clastic dike material. This requires recrystallization of at least some of the carbonate under cold conditions and likely results from precipitation of small amounts of carbonate while at the cold surface exposed to me- 


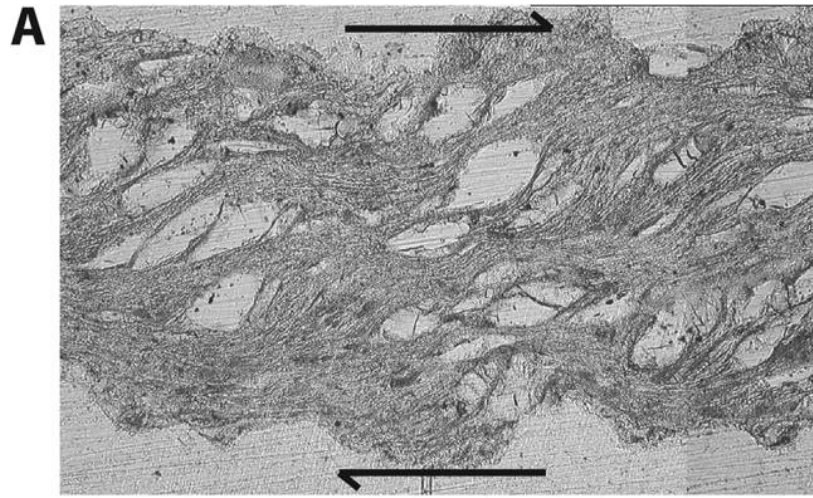

B

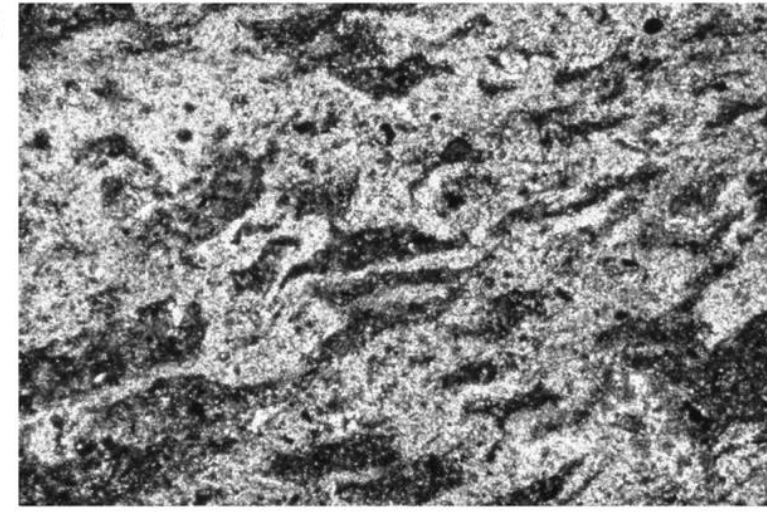

C

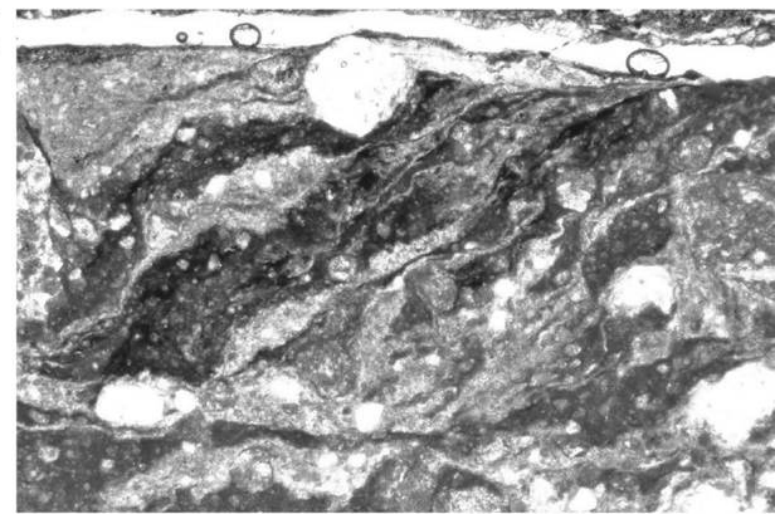

Figure 11. Photomicrographs of sigmoid-shaped grains. $A$, Those generated by high-strain brittle-viscous creep via pressure solution, using halite-kaolinite aggregates (from Bos and Spiers 2001, their fig. 5c). B, Deformed basal Bighorn Formation from just below the detachment, Pilot Creek. Sigmoidal carbonate pods resemble features in $A$ associated with viscous creep. $C$, Footwall immediately below $(0-2 \mathrm{~mm})$ the Heart Mountain detachment, showing brittle shear and the formation of sigmoidal banding similar to the experimental texture in $A$. Width of view in $B$ and $C$ is $2.2 \mathrm{~mm}$, and long axis is parallel to the detachment in $B$ and $C$. A color version of this figure is available online.

teoric water. These data do not show any signs of recrystallization under high temperature conditions, as might be expected from frictional heating or injection of volcanic gases along a fault.

\section{Discussion}

Brecciation and Veining Events. Both mesoscopic and microscopic evidence described above, as well as similar observations by Hauge $(1985,1990)$, provide abundant evidence for multicyclic fragmentation, clastic diking, and pressure solution events along the detachment plane, casting serious doubt on the hypothesis that emplacement of the entire allochthon was a single catastrophic event. As we discuss below, we suspect not only that emplacement was not catastrophic but that the key evidence previously used in favor of it (i.e., the banded grains) may instead be interpreted as evidence in favor of gradual emplacement by a combination of cataclastic flow (pressure-sensitive rheology) and viscous flow (ratesensitive rheology) over a protracted period of time.

Evidence for multiple slip events, in the form of clasts of breccia within younger breccia, has been presented previously, including by researchers who interpret the slip along the Heart Mountain detachment to be catastrophic (see Anders et al. 2010, their fig. 4e; Craddock et al. 2009, their fig. 3; Beutner and Gerbi 2005, their figs. 6 and 7; Beutner and Craven 1996, their fig. 4). However, these authors all dismiss this brecciation as either deformation that occurred earlier during the catastrophic event (Anders et al. 2000) or "pre-Heart Mountain detachment deformation" (Craddock et al. 2009). They do not explain their reasons for interpreting the deformation that was observed only along the Heart Mountain detachment as being unrelated to slip along that fault. We believe the more likely explanation for multiple phases of brecciation along the fault is that it experienced multiple slip events.

In addition to multiple brecciation events, there is evidence for multiple and protracted periods of vein formation, as shown in figure $6 B$. Changes in the orientations of the calcite fibers within individual veins indicate deformation during vein growth. A later, more iron-rich fluid resulted in crystallization of the en echelon structure apparent in figure $6 B$.

Banded Grains. Previous studies discussing the presence of banded grains similar to those in figures 7 and 8 interpret them as having formed during suspension within a pressurized fluid at the base of the detachment, constituting evidence of catastrophic slip (Hughes 1970; Beutner and Craven 1996; Beutner and Gerbi 2005; Craddock et al. 2009, 2012; Anders et al. 2010). In the discussion of the processes that might have created the banded grains, the analogues of volcanic accretionary lapilli and impact ejecta were invoked, with an interpreted fluid of volcanic gas preferred for Heart Mountain (e.g., Beutner and Gerbi 2005). However, in these ana- 
Table 1. Isotopic Data on Two-Toned Clastic Dike (Fig. 4E) and Host Rock

\begin{tabular}{lcccc}
\hline Sample ID & $\delta^{13} \mathrm{C}(\mathrm{VPDB})$ & $\delta^{18} \mathrm{O}$ mineral $(\mathrm{VSMOW})$ & Temperature $\left({ }^{\circ} \mathrm{C}\right)$ & $\delta^{18} \mathrm{O}$ water $(\mathrm{VSMOW})$ \\
\hline ES-HM13-41 TA & -.48 & 24.98 & 55.5 & -.56 \\
ES-HM13-41 TB & -.47 & 24.96 & 51.4 & -1.24 \\
ES-HM13-41 TC & -.53 & 25.01 & 53.0 & -.93 \\
ES-HM13-41 TD & -.48 & 24.59 & 36.2 & -4.20 \\
ES-HM13-41 TE & -.55 & 24.78 & 42.2 & -2.95 \\
ES-HM13-41 TF & -.56 & 24.92 & 41.4 & -2.94 \\
Host Bighorn Formation & 1 to -1 & 23 to 27 & 50 to 65 & -3 to 2 \\
\hline
\end{tabular}

Note. $\quad \mathrm{VPDB}=$ Vienna Pee Dee belemnite; VSMOW = Vienna standard mean ocean water.

logues the clasts with accretionary rims make up a very high percentage of the rock - at least $90 \%$ (see Beutner and Gerbi 2005, their figures 8-10)-and the remaining $10 \%$ of material is the matrix, not uncoated grains. Later authors adopted the same mechanism of suspension in a fluid to explain the presence of "accreted grains," albeit with an interpreted $\mathrm{CO}_{2}$ fluid, formed from massive decomposition of carbonate during frictional heating (e.g., Anders et al. 2010). If the same accretionary processes are present along the Heart Mountain detachment, a similarly large proportion of accreted grains might be expected, but this is nowhere observed. Additionally, one might expect that suspension would affect grains according to size, with the smaller grains, which are more likely to be suspended, preferentially showing coatings. There is no apparent correlation between the size of the grains that have rims and the size of those that do not in the examples in figures 7 and 8 .

We prefer the interpretation that these grains formed by alteration and dissolution processes rather than accretionary processes. Close inspection of the surfaces bounding many of the banded grains shows a remarkable similarity in texture, color, and general appearance to stylolites. Only the overall round form appears to distinguish them from typical stylolites. The process that could produce a spherical or ellipsoidal pattern of dissolution is not clear, but such patterns are not unknown (fig. 8F). A sample from a low-angle detachment within carbonate in the Mormon Mountains in Nevada shows an example of a continuous stylolite with locally developed ellipsoidal geometry. Perhaps this represents an early stage of formation of the banded grains.

It is possible that the formation of banded grains involves a solution process similar to the production of corestones in weathered granite. In corestone formation, the material within the corestone is compositionally exactly the same as the surrounding material but experienced less weathering. These banded grains might be similar in that they are simply regions that experienced less dissolution that the surrounding rock. This explanation is speculative and independent of the fact that the rocks are likely undergoing shear deformation, but its strengths include explanations for (1) the low percentage of concen- trically banded grains, (2) the lack of correlation between grain size and putative accretion, (3) the variability of compositions of the grain cores, and, perhaps most importantly, (4) the truncation of matrix grains by the banding (e.g., fig. $8 B$ ). This possibility was acknowledged by Beutner and Gerbi (1996, p. 728) but was not preferred because of a lack of insoluble residues and their observations that "small carbonate grains in contact with films show no evidence of grain shaping by dissolution." Our petrographic observations show that both of these types of features are present (figs. 7, 8B).

Banded grains, also referred to as clast-cortex grains, have been described along rooted faults, including the carbonate-hosted Tre Monti fault in Italy (Smith et al. 2011). This texture was proposed to be a potential indicator of rapid slip, in part because of the similarity to "armoured carbonate grains found within the basal detachment horizons of catastrophic landslides," with the citations referring solely to studies of the Heart Mountain basal layer (Smith et al. 2011, p. 2386). These authors wanted experimental validation before using this texture as evidence of rapid slip. Such experiments were recently performed by Rempe et al. (2014) and showed that these "clast-cortex aggregates" formed at slip rates ranging from $100 \mathrm{~mm} / \mathrm{s}$ to $1 \mathrm{~m} / \mathrm{s}$ (the full range tested), but only at relatively low normal stresses. Han and Hirose (2012) created similar concentrically banded grains (their "clay-clast aggregates") via experiments using quartz-bentonite gouges, including at slip rates three orders of magnitude slower than seismic slip rates $(0.0005 \mathrm{~m} / \mathrm{s})$. These studies suggest that this texture is not a reliable indicator of rapid slip rates.

Mechanism for Slip on the Heart Mountain Detachment. A potential mechanism that may have facilitated slip on the apparently unfavorably oriented Heart Mountain detachment is pressure solution creep along the detachment surface that occurs in discontinuous patches. The creep elastically loads areas of the fault between the patches with additional subhorizontal shear tractions. Such loading may have the effect of locally rotating the principal stress directions in the vicinity of the fault, enabling both the initiation and the continued slip via brittle 

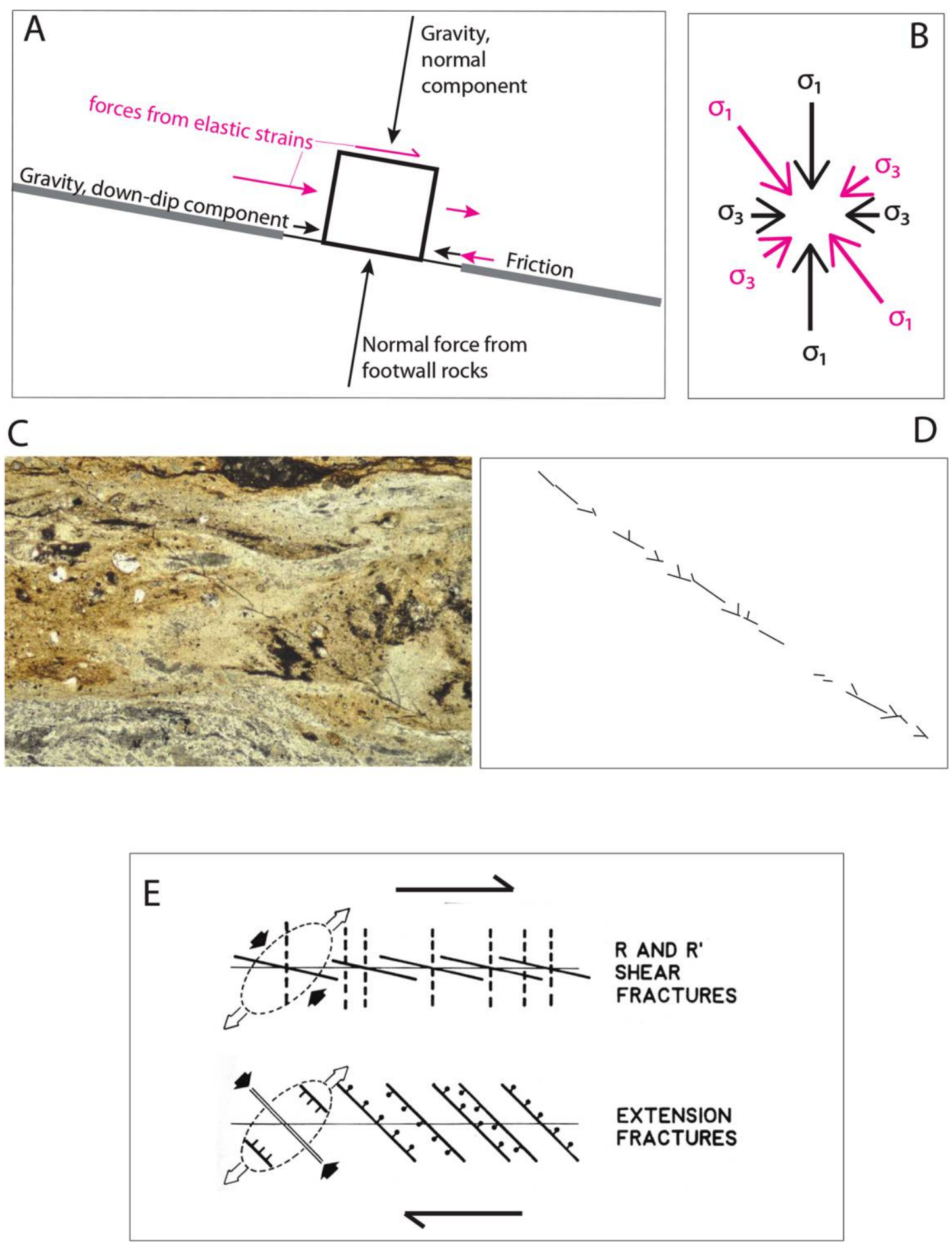

Figure 12. Diagrams showing rotation of principal stress axes due to elastic forces. $A$, Schematic block diagram showing the forces on an arbitrary piece of rock on a low-angle fault, here dipping $10^{\circ}$, with creeping sections (thick gray lines) and a noncreeping section (thin black line). Forces from gravity and friction are shown with black arrows, and those that would result from the elastic strain in neighboring rocks are shown with red arrows. $B$, Principal stress orientations predicted from just gravity and friction (black) and from the inclusion of elastic forces (red). $C$, Detachment gouge from Jim Smith Creek overprinted with Riedel shear fractures. D, Drawing highlighting the orientations of fractures in C. E, Diagram from Sylvester (1988) showing the orientations of Riedel and tensional fractures predicted from the given maximum principal compression direction (black arrows) and the least compressive direction (white arrows). 
failure on the detachment surface (fig. 12A). A section of fault that is not creeping (or creeping much more slowly) by pressure solution and reprecipitation is shown in the middle (with a thin black line), with sections that creep on either side /thick gray line). The section that does not creep will experience forces due to gravity, the upward normal force from the footwall, and an updip force due to friction (all black arrows), but also an additional down-dip shear traction from elastic strain (red arrows). The inclusion of elastic forces in the force diagrams results in a different state of stress from that predicted solely from gravity and in locally nonvertical maximum compressive stress (fig. 12B).

A maximum compressive stress that is not vertical can resolve the stress paradox. With sufficient forcing from elastic strain, surfaces at low angle to the horizontal can become the preferred brittle failure direction. Under these conditions, any slight elevation of pore fluid pressure or increase in differential stress would cause brittle failure and smallmagnitude displacement along the low-angle plane, including the parts that were previously creeping. The majority of the slip along the detachment need not be accommodated by pressure solution creep for this mechanism to apply.

Supporting evidence for nonvertical principal stress directions in the vicinity of the fault may be found in Riedel shear fractures that cross-cut finegrained breccia along the detachment at Jim Smith Creek (fig. 12C, 12D) as well as the geometry of en echelon clastic dikes mentioned earlier (fig. 4D). These Riedel fractures either result from late-stage motion along the detachment or are postdetachment in age. At present, the detachment breccia layer is nearly horizontal and is cut by shear fractures that are at $\sim 80^{\circ}$ and $\sim 20^{\circ}$ to the horizontal. This corresponds to an orientation of maximum compressive stress at $\sim 50^{\circ}$ to the horizontal and a minimum compressive stress at $40^{\circ}$ (e.g., Sylvester 1988), indicating that the principal stresses were inclined at the time of fracture (fig. 12B, 12C).

The process of elastic loading could result from any number of deformation processes, including calcite twinning, brittle creep, or other low-temperature deformation mechanisms. It is the discontinuous nature of the deformation that is responsible for the elastic loading, not the specific mechanism itself. We chose to focus on pressure solution creep because of its prevalence in the samples we observed, but we do not expect it to be the only important process here or along other low-angle faults.

This cyclic pressure solution-precipitation-slip model for motion on low-angle or unfavorably oriented fault zones could explain several otherwise enigmatic observations related to the Heart Mountain detachment. In particular, given that the coulombic failure strength of shale is as much as a factor of two to three lower than dolomite, why did the detachment localize near the base of the Ordovician dolomite layer, just above the shales? Why did it fail to break at a higher angle? Pressure solution may provide an answer to both of these questions. Under the pressure solution deformation regime, the high permeability of dolostone may make it more prone to dissolution.

\section{Conclusions}

Abundant evidence indicates that the Heart Mountain detachment moved multiple times, with some lines of evidence requiring five or more episodes of slip. Many more than five phases of deformation are envisioned, but the process of multiple overprinting renders the local preservation of many more events unlikely. Many of the detachment-related rocks exhibit fault zone textures and footwall deformation that suggest a complex and protracted history of deformation. Pressure solution features are common, must form between brittle events, and likely play a role in the cyclic deformation of the Heart Mountain allochthon. The observation most commonly used in support of a single catastrophic event and fluidization of the basal layer, the banded grains, is here reinterpreted to indicate slow deformation due to dissolution and alteration. No catastrophic displacement events are envisioned.

We suggest that local patches of pressure solution creep along bedding within dolomite near the base of the carbonate section imposed shear tractions on intervening areas, resulting in coulombic failure and subsequent brittle slip on the low-angle Heart Mountain detachment. This pressure solution model uniquely resolves the two primary enigmas of Heart Mountain faulting: it provides a mechanism for rotation of the stress field, permitting initiation of and continued noncatastrophic displacement along the subhorizontal rootless detachment; and it explains why a bedding surface within dolomite rather than within thick underlying shale was the favored location for the detachment.

\section{A C K N O W LED G M ENTS}

This research was supported by National Science Foundation grant EAR 12-50565 awarded to B. P. Wernicke and J. Eiler and by the Gordon and Betty Moore Foundation. 


\section{REFEREN CES CITED}

Aharonov, E., and Anders, M. H. 2006. Hot water: a solution to the Heart Mountain detachment problem? Geology 34:165-168.

Allmendinger, R. W.; Sharp, J. W.; Von Tish, D.; Serpa, L.; Kaufman, S.; Oliver, J.; and Smith, R. B. 1983. Cenozoic and Mesozoic structure of the eastern Basin and Range Province, Utah, from COCORP seismic reflection data. Geology 11:532-536.

Anders, M. H.; Aharonov, E.; and Walsh, J. J. 2000. Stratified granular media beneath large slide blocks: implications for mode of emplacement. Geology 28: 971-974.

Anders, M. H.; Fouke, B. W.; Zerkle, A. L.; Tavarnelli, E.; Alvarez, W.; and Harlow, G. E. 2010. The role of calcining and basal fluidization in the long runout of carbonate slides: an example from the Heart Mountain Slide Block, Wyoming and Montana, U.S.A.I. Geol. 118:577-599.

Anders, M. H.; Schneider, J. R.; Scholz, C. H.; and Losh, S. 2013. Mode I microfracturing and fluid flow in damage zones: the key to distinguishing faults from slides. I. Struct. Geol. 48:113-125.

Anderson, R. E.; Felger, T. J.; Diehl, S. F.; Page, W. R.; and Workman, J. B. 2010. Integration of tectonic, sedimentary and geohydrologica processes leading to smallscale extension model for the Mormon mountains area north of Lake Mead, Lincoln County, Nevada. In Umhoefer, P. J.; Beard, L. S.; and Lamb, M. A., eds. Miocene tectonics of the Lake Mead region, Central Basin and Range. Geol. Soc. Am. Spec. Pap. 463:395-426.

Armstrong, R. L. 1972. Low-angle (denudation) faults, hinterland of the Sevier orogenic belt, eastern Nevada and western Utah. Geol. Soc. Am. Bull. 83:1729-1754.

Axen, G. J. 2004. Mechanics of low-angle normal faults. In Karner, G. D.; Taylor, B.; Driscoll, N. W.; and Kohlstedt, D. L., eds. Rheology and deformation of the lithosphere at continental margins. New York, Columbia University Press, p. 46-91.

Beutner, E. C., and Craven, A. E. 1996. Volcanic fluidization and the Heart Mountain detachment, Wyoming. Geology 24:595-598.

Beutner, E. C., and Gerbi, G. P. 2005. Catastrophic emplacement of the Heart Mountain block slide, Wyoming and Montana, USA. Geol. Soc. Am. Bull. 117:724-735.

Beutner, E. C., and Hauge, T. A. 2009. Heart Mountain and South Fork fault systems: architecture and evolution of the collapse of an Eocene volcanic system, northwest Wyoming. Rocky Mt. Geol. 44:147-164.

Bos, B., and Spiers, C. J. 2001. Experimental investigation into the microstructural and mechanical evolution of phyllosilicate-bearing fault rock under conditions favouring pressure solution. I. Struct. Geol. 23:11871202.

Bucher, W. H. 1947. Heart Mountain problem. In Blackstone, D. L., Jr., and Sternberg, C. W., eds. Field Conference Guidebook, field conference in the Bighorn basin. Wyoming Geol. Assoc., p. 189-197.
Collettini, C. 2011. The mechanical paradox of low-angle normal faults: current understanding and open questions. Tectonophysics 510:253-268.

Collettini, C., and Holdsworth, R. E. 2004. Fault zone weakening and character of slip along low-angle normal faults: insights from the Zuccale fault, Elba, Italy. I. Geol. Soc. Lond. 161:1039-1052.

Collettini, C., and Sibson, R. H. 2001. Normal faults, normal friction? Geology 29:927-930.

Cowan, D. S.; Cladouhos, T. T.; and Morgan, J. K. 2003. Structural geology and kinematic history of rocks formed along low-angle normal faults, Death Valley, California. Geol. Soc. Am. Bull. 115:1230-1248.

Craddock, J. P.; Geary, J.; and Malone, D. H. 2012. Vertical injectites of detachment carbonate ultracataclasite at White Mountain, Heart Mountain detachment, Wyoming. Geology 40:463-466.

Craddock, J. P.; Malone, D. H.; Magloughlin, J.; Cook, A. L.; Rieser, M. E.; and Doyle, J. R. 2009. Dynamics of the emplacement of the Heart Mountain allochthon at White Mountain: constraints from calcite twinning strains, anisotropy of magnetic susceptibility, and thermodynamic calculations. Geol. Soc. Am. Bull. 121:919938.

Dake, C. L. 1918. The Hart Mountain overthrust and associated structures in Park County, Wyoming. I. Geol. 26:45-55

Davis, G. A. 1965. Discussion on "Role of fluid pressure in mechanics of overthrust faulting." GSA Bull. 76: 463-474.

Davis, G. H., and Coney, P. J. 1979. Geologic development of Cordilleran metamorphic core complexes. Geology 7:120-124.

Douglas, T. A.; Chamberlain, C. P.; Poage, M. A.; Abruzzese, M.; Schultz, S.; Henneberry, J.; and Layer, P. 2003. Fluid flow and the Heart Mountain fault: a stable isotopic, fluid inclusion, and geochronologic study. Geofluids 3:13-32.

Eiler, J. M. 2007. "Clumped-isotope" geochemistry-the study of naturally-occurring, multiply-substituted isotopologues. Earth Planet. Sci. Lett. 262:309-327.

- 2011. Paleoclimate reconstruction using carbonate clumped isotope thermometry. Quat. Sci. Rev. 30:3575-3588

Eldridge, G. H. 1894. A geological reconnaissance in northwestern Wyoming. U.S. Geol. Surv. Bull. 119, 72 p.

Engelder, T. 1979. Mechanisms for strain within the Upper Devonian clastic sequence of the Appalachian Plateau, western New York. Am. I. Sci. 279:527-542.

Feeley, T. C., and Cosca, M. A. 2003. Time vs. composition trends of magmatism at Sunlight volcano, $\mathrm{Ab}$ saroka volcanic province, Wyoming. Geol. Soc. Am. Bull. 115:714-728.

Fisher, C. A. 1906. Geology and water resources of the Bighorn basin, Wyoming. U.S. Geol. Sur. Prof. Pap. 53, 72 p.

Goren, L.; Aharonov, E.; and Anders, M. H. 2010. The long runout of the Heart Mountain landslide: heating, 
pressurization, and carbonate decomposition. J. Geophys. Res. 115:B10.

Gratier, J.-P.; Dysthe, D. K.; and Renard, F. O. 2013. The role of pressure solution creep in the ductility of the Earth's upper crust. Adv. Geophys. 54:47-179.

Gratier, J.-P.; Favreau, P.; Renard, F.; and Pili, E. 2002. Fluid pressure evolution during the earthquake cycle controlled by fluid flow and pressure solution crack sealing. Earth Planets Space 54:1139-1146.

Guo, W. F.; Mosenfelder, J. L.; Goddard, W. A., III; and Eiler, J. M. 2009. Isotopic fractionations associated with phosphoric acid digestion of carbonate minerals: insights from first-principles theoretical modeling and clumped isotope measurements. Geochim. Cosmochim. Acta 73:7203-7225.

Han, R., and Hirose, T. 2012. Clay-clast aggregates in fault gouge: an unequivocal indicator of seismic faulting at shallow depths? I. Struct. Geol. 43:92-99.

Hauge, T. A. 1982. The Heart Mountain detachment fault, northwest Wyoming: involvement of Absaroka volcanic rock. Geology of the Yellowstone Park area, 33rd Annual Field Conference of the Wyoming Geological Association, p. 175-179.

- 1983. Geometry and kinematics of the Heart Mountain detachment fault, northwestern Wyoming and Montana. PhD dissertation, University of Southern California, Los Angeles.

- 1985. Gravity-spreading origin of the Heart Mountain allochthon, northwestern Wyoming. Geol. Soc. Am. Bull. 96:1440-1456.

1990. Kinematic model of a continuous Heart Mountain allochthon. Geol. Soc. Am. 102:1174-1188. 1993a. The Heart Mountain detachment, northwestern Wyoming: 100 years of controversy. In Snoke, A. W.; Steidtmann, J. R.; and Roberts, S. M., eds. Geology of Wyoming. Geol. Surv. Wyo. Mem. 5, p. 530-571.

1993b. A speedometer for the Heart Mountain allochthon, Wyoming. Geol. Soc. Am. Abstr. Programs 25:49.

Hiza, M. M. 2000. The geochemistry and geochronology of the Eocene Absaroka Volcanic Province, northern Wyoming and southwest Montana, USA. PhD dissertation, Oregon State University, Corvallis, 240 p.

Hubbert, M. K., and Rubey, W. W. 1959. Role of fluid pressure in mechanics of overthrust faulting. I. Mechanics of fluid-filled porous solids and its application to overthrust faulting. Geol. Soc. Am. Bull. 70:115166.

Hughes, C. J. 1970. The Heart Mountain detachment fault: a volcanic phenomenon? I. Geol. 78:107-116

Huntington, K. W.; Eiler, J. M.; Affek, H. P.; Guo, W.; Bonifacie, M.; Yeung, L. Y.; Thiagarajan, N.; et al. 2009. Methods and limitations of "clumped" $\mathrm{CO}_{2}$ isotope $(\Delta 47)$ analysis by gas-source isotope ratio mass spectrometry. I. Mass Spectrom. 44:1318-1329.

Lister, G. S., and Davis, G. A. 1989. The origin of metamorphic core complexes and detachment faults formed during Tertiary continental extension in the northern Colorado River region, U.S.A. I. Struct. Geol. 11:65-94.
Melosh, H. J. 1983. Acoustic fluidization: can sound waves explain why dry rock debris appears to flow like a fluid in some energetic geologic events? Am. Sci. $71: 158-165$.

Morley, C. K. 2014. The widespread occurrence of lowangle normal faults in a rift setting: review of examples from Thailand, and implications for their origin and evolution. Earth Sci. Rev. 133:18-42.

Nelson, W. H.; Prostka, H. J.; and Williams, F. E. 1980. Geology and mineral resources of the North Absaroka Wilderness and vicinity, Park County, Wyoming. U.S. Geol. Surv. Bull. 1447, 101 p.

O'Neil, J. R.; Clayton, R. N.; and Mayeda, T. K. 1969. Oxygen isotope fractionation in divalent metal carbonates. I. Chem. Phys. 51:5547-5558.

Pierce, W. G. 1957. Heart Mountain and South Fork detachment thrusts of Wyoming. AAPG Bull. 41:591-626.

. 1960. The "break-away" point of the Heart Mountain detachment fault in northwestern Wyoming. U.S. Geol. Surv. Prof. Pap. 400-B:B236-B237.

- 1965a. Geologic map of the Clark quadrangle, Park County, Wyoming. U.S. Geol. Surv. Quadrang. Map GQ-477, scale 1:62,500.

—. 1965b. Geologic map of the Deep Lake quadrangle, Park County, Wyoming. U.S. Geol. Surv. Quadrang. Map GQ-478, scale 1:62,500.

. 1966. Geologic map of the Cody quadrangle, Park County, Wyoming. U.S. Geol. Surv. Quadrang. Map GQ-542, scale $1: 62,500$.

. 1973. Principal features of the Heart Mountain fault, and the mechanism problem. In DeJong, K. A., and Scholten, R., eds. Gravity and tectonics. New York, Wiley, p. 457-471.

- 1978. Geologic map of the Cody $10 \times 2 \mathrm{O}$ quadrangle, northwestern Wyoming. U.S. Geol. Surv. Misc. Field Stud. Map MF-963, scale 1:62,500.

. 1979. Clastic dikes of the Heart Mountain fault breccia, northwest Wyoming, and their significance. U.S. Geol. Surv. Prof. Pap. 1133, 25 p.

1980. The Heart Mountain break-away fault, northwestern Wyoming. Geol. Soc. Am. Bull. 91:272281.

Pierce, W. G., and Nelson, W. H. 1968. Geologic map of the Pat O'Hara Mountain quadrangle, Park County, Wyoming. U.S. Geol. Surv. Quadrang. Map GQ-755, scale $1: 62,500$.

. 1969. Geologic map of the Wapiti quadrangle, Park County, Wyoming. U.S. Geol. Surv. Quadrang. Map GQ-778, scale 1:62,500.

. 1971. Geologic map of the Beartooth Butte quadrangle, Park County, Wyoming. U.S. Geol. Surv. Quadrang. Map GQ-935, scale 1:62,500.

Pierce, W. G.; Nelson, W. H.; and Prostka, H. J. 1973. Geologic map of the Pilot Peak quadrangle, Park County, Wyoming and Park County, Montana. U.S. Geol. Surv. Misc. Investig. Map I-816, scale 1:62,500.

1982. Geologic map of the Dead Indian Peak quadrangle, Park County, Wyoming. U.S. Geol. Surv. Quadrang. Map GQ-1564, scale 1:62,500. 
Prostka, H. J.; Ruppel, E. T.; and Christiansen, R. L. 1975. Geologic map of the Abiathar Peak quandrangle, Yellowstone National Park, Wyoming and Montana. U.S. Geol. Surv. Quadrang. Map GQ-1244, scale 1: $62,500$.

Rempe, M.; Smith, A. F.; Ferri, F.; Mitchell, T. M.; and Di Toro, G. 2014. Clast-cortex aggregates in experimental and natural calcite-bearing fault zones. I. Struct. Geol. 68:142-157.

Rosenbaum, J., and Sheppard, S. M. F. 1986. An isotopic study of siderites, dolomites and ankerites at high temperatures. Geochim. Cosmochim. Acta 50:1147-1150.

Rubey, W. W., and Hubbert, M. K. 1959. Role of fluid pressure in mechanics of overthrust faulting. Geol. Soc. Am. Bull. 70:167-206.

Rutter, E. H. 1983. Pressure solution in nature, theory and experiment. I. Geol. Soc. Lond. 140:725-740.

Sales, J. K. 1983. Heart Mountain: blocks in a giant volcanic rock glacier. 34th Annual Field Conference Guidebook of the Wyoming Geological Association, p. 117-165.

Schauble, E. A.; Ghosh, P.; and Eiler, J. M. 2006. Preferential formation of ${ }^{13} \mathrm{C}-{ }^{18} \mathrm{O}$ bonds in carbonate minerals, estimated using first-principles lattice dynamics. Geochim. Cosmochim. Acta 70:2510-2529.

Smith, S. A. F.; Billi, A.; Toro, G. D.; and Spiess, R. 2011. Principal slip zones in limestone: microstructural characterization and implications for the seismic cycle (Tre Monti fault, central Apennines, Italy). Pure Appl. Geophys. 168:2365-2393.

Swanson, E. M. 2015. Structural and clumped isotope constraints on the mechanisms of displacement along low-angle detachments. PhD dissertation, California Institute of Technology, Pasadena.

Swanson, E. M.; Wernicke, B. P.; Eiler, J. M.; and Losh, S. 2012. Temperatures and fluids on faults based on carbonate clumped-isotope thermometry. Am. I. Sci. 312:1-21.

Sylvester, A. G. 1988. Strike-slip faults. Geol. Soc. Am. Bull. 100:1666-1703.

Templeton, A. S.; Sweeney, J. J.; Manske, H.; Tilghman, J. F.; Calhoun, S. C.; Violich, A.; and Chamberlain, C. P. 1995. Fluids and the Heart Mountain fault revisited. Geology 23:929-932.

Vasconcelos, C.; McKenzie, J. A.; Warthmann, R.; and Bernasconi, S. M. 2005. Calibration of the $\delta^{18} \mathrm{O}$ paleothermometer for dolomite precipitated in microbial cultures and natural environments. Geology 33:317320.

Voight, B. 1973. The mechanics of retrogressive blockgliding, with emphasis on the evolution of the Turnagain Heights landslide, Anchorage, Alaska. In DeJong, K. A., and Scholten, R., eds. Gravity and tectonics. New York, Wiley, p. 97-121.

Wernicke, B. 1995. Low-angle normal faults and seismicity: a review. J. Geophys. Res. 100:20,159.

Wernicke, B.; Walker, J. D.; and Beaufait, M. S. 1985. Structural discordance between Neogene detachments and frontal sevier thrusts, central Mormon Mountains, southern Nevada. Tectonics 4:213-246.

Wright, T. O., and Platt, L. B. 1982. Pressure dissolution and cleavage in the Martinsburg Shale. Am. I. Sci. 282:122135. 